\title{
Mesoscale circulation systems and ozone concentrations during ESCOMPTE: a case study from IOP $2 b$
}

\author{
N. Kalthoff ${ }^{\text {a,* }}$, C. Kottmeier ${ }^{\mathrm{a}}$, J. Thürauf ${ }^{\mathrm{a}}$, U. Corsmeier ${ }^{\mathrm{a}}$, F. Saïd ${ }^{\mathrm{b}}$, \\ E. Fréjafon ${ }^{\mathrm{c}}$, P.E. Perros ${ }^{\mathrm{d}}$ \\ anstitut für Meteorologie und Klimaforschung, Forschungszentrum Karlsruhe/Universität Karlsruhe, \\ Postfach 3640, 76021 Karlsruhe, Germany \\ bLaboratoire d'Aérologie, UPS/CNRS, UMR 5560 Toulouse, France \\ ${ }^{\mathrm{c}}$ INERIS, Verneuil en Halatte, France \\ ${ }^{\mathrm{d}}$ LISA, Université de Paris XII, UMR 7583, Créteil, France
}

The main objective of 'Expérience sur Site pour COntraindre les Modèles de Pollution atmosphérique et de Transport d'Emissions' (ESCOMPTE) is to generate a relevant data set for testing and evaluating mesoscale chemistry-transport models (CTMs). During ESCOMPTE, measurements have been performed at numerous surface stations, by radars and lidars, and several aircraft in the planetary boundary layer. The data from these different sources have been merged to obtain a consistent description of the spatial distribution of wind, temperature, humidity, and ozone for the photosmog episode on June 25, 2001 (IOP 2b).

On this day, moderate synoptic winds favour the evolution of different mesoscale circulation systems. During daytime, the sea breeze penetrates towards the north in the Rhône valley. As the winds above the sea breeze layer come from the east, polluted air from the metropolitan area of Marseille leads to an increase of ozone at elevated layers above the convective boundary layer (CBL). At the mountainous station of Luberon about $55 \mathrm{~km}$ north of Marseille around noon, when the CBL top surpasses the height of the mountain summit, polluted air with ozone concentrations of about 120 ppbv arrived from southerly directions, thus indicating the passage of the city plume of Marseille. At Cadarache and Vinon in the Durance valley, about $60 \mathrm{~km}$ inland, the ozone maximum

\footnotetext{
* Corresponding author. Tel.: +49 7247 824230; fax: +49 7247824377 .

E-mail address: norbert.kalthoff@imk.fzk.de (N. Kalthoff).
} 
at the surface and at flight level $920 \mathrm{~m}$ MSL appears between 14 and 15 UTC. At this time, southwesterly valley winds prevail in the valley, while southerly winds occur above. This finding highlights the height-dependent advection of ozone due to interacting mesoscale circulation systems. These dynamical processes need to be represented adequately in CTMs to deliver a realistic description of the ozone concentration fields.

Keywords: Summer smog; Ozone; Mesoscale circulation systems; ESCOMPTE; Marseille city plume

\section{Introduction}

Transport and dispersion of air pollutants are strongly influenced by meteorological conditions. Over complex terrain, the meteorological conditions normally are a combination of large-scale flow and orographically/thermally induced circulation systems, such as land-sea breeze, slope winds, valley-mountain, and plain-plateau winds. These latter mesoscale circulations are caused by non-homogeneous surface conditions and, often, conditions for the evolution of more than one mesoscale circulation system exist at one site. Hence, merging of the mesoscale circulation systems may contribute to longrange transport of air masses (Kurita, 1990). In many cases, cities with large industrial agglomerations are situated in coastal regions so that mesoscale circulation systems play an important role for the ventilation of such areas and determine how far polluted air propagates inland. The importance of mesoscale circulation systems to air pollutant transport has already been emphasized by various investigations (Carroll and Baskett, 1979; Wakimoto and McElroy, 1986; Kurita et al., 1990; Klemm et al., 1998; BischoffGauß et al., 1998).

Airborne pollutants in transit do not only undergo diffusion, but also chemical transformation and deposition. Therefore, highest concentrations of secondary pollutants like ozone often do not appear in the vicinity of cities, but some tens of kilometres downwind (Vogel et al., 1992; Imhoff et al., 1995; Corsmeier et al., 2002; Hammer et al., 2002; Vautard et al., 2003). This means that both modelling of the mesoscale wind and diffusion conditions as well as modelling of the chemical transformation are necessary for a precise forecast of so-called summer smog episodes (Schaller et al., 2001). Up to now, however, appropriate data sets for testing mesoscale chemistry-transport models (CTMs) are scarce, especially over complex terrain (Cros et al., 2004), although some data sets have been collected during recent experiments like MEDCAPHOT-TRACE (Ziomas, 1998), BERLIOZ (Becker et al., 2002; Corsmeier et al., 2002), PIPAPO (Neftel, 1999), and ESQUIF (Menut et al., 2000), for Athens, Berlin, Milano and Paris, respectively, and VOTALP (Wotawa and Kromp-Kolb, 2000) and MAP (Bougeault and Binder, 2002) for the Alps.

The city of Marseille with 1.2 million inhabitants combines all features mentioned above. As it is situated in the southeastern part of France on the Mediterranean coast with mountains and valleys in the hinterland, sea breeze and mountain winds characterize the meteorological conditions. High temperatures in summer and high emission rates of ozone precursors favour the development of summer smog episodes. Therefore, the experiment 
'Expérience sur Site pour COntraindre les Modèles de Pollution atmosphérique et de Transport d'Emissions' (ESCOMPTE) was performed in the area of Marseille in summer 2001, the main objective being to establish a detailed 4-D data set with air chemistry and meteorological data for high pollution events (Cros et al., 2004).

This investigation focuses on one of the intensive operation periods, namely IOP $2 b$, analysing the mesoscale circulation systems and the air pollutant distribution within the planetary boundary layer (PBL) using surface, remote sensing, and airborne observation data. The paper is structured as follows: In the next section, a site description is given, including an overview of the synoptic conditions. In Section 3, mesoscale circulation systems are investigated with respect to space and time, and in Section 4, the spatial ozone distribution in conjunction with the meteorological situation is analysed.

\section{Measurement area, available data, and synoptic conditions on IOP $2 \mathrm{~b}$}

\subsection{Measurement area and available data}

During the ESCOMPTE experiment, a network of surface stations for meteorological (S) and air chemistry measurements $(\mathrm{O})$ was installed, which covers the metropolitan area of Marseille, the industrialised bay area west of Marseille (Etang de Berre) as well as the surrounding hillsides north of the city and the dominating valleys like the Rhône and Durance valley. The positions of the different measuring systems are indicated in Fig. 1,

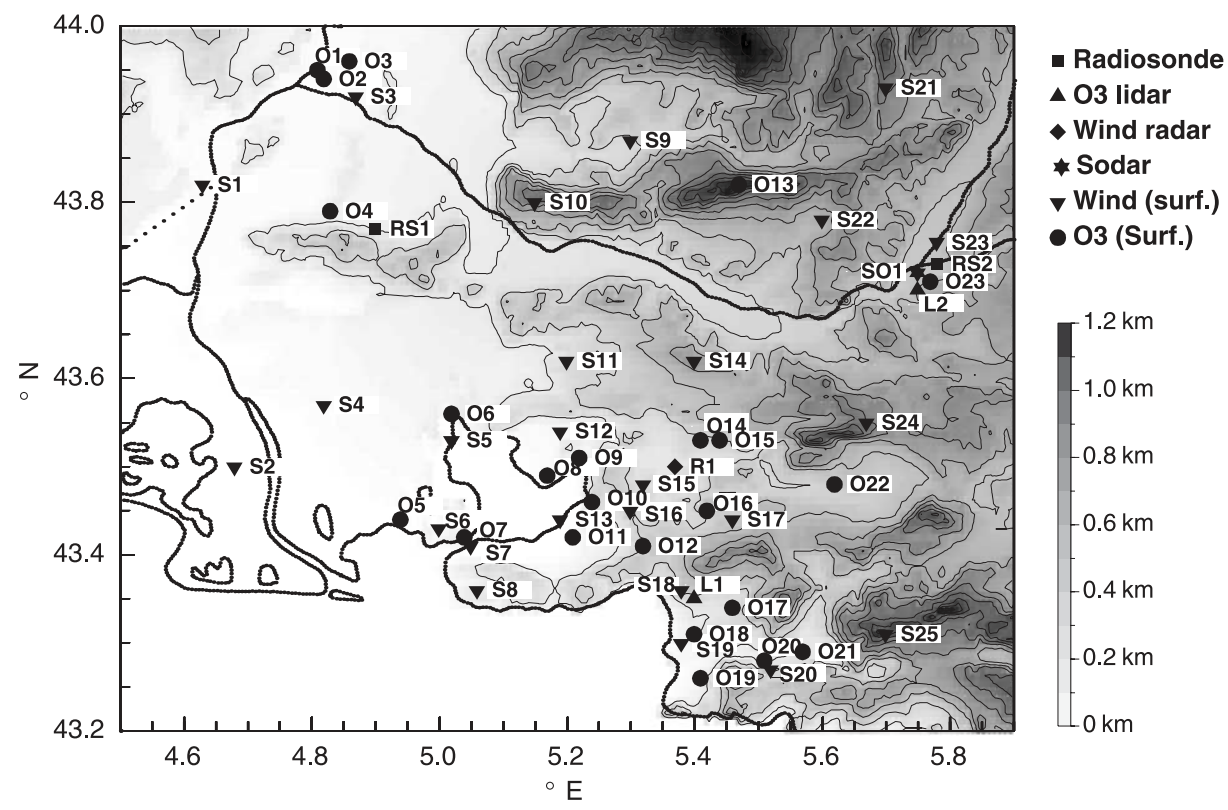

Fig. 1. Positions of the stations in the ESCOMPTE domain. The corresponding names of the stations are given in Table 1 . The grey scale indicates the height of orography. 
the names of the stations are summarized in Table 1. Ozone lidar (L) and sodar (SO) additionally supplied continuous vertical profiles of ozone and wind, respectively. Radiosondes measured profiles of the meteorological components in 3-h intervals during the IOPs, e.g., in the Rhône (RS1) and Durance valleys (RS2). On IOP 2b (June 25, 2001), two aircraft were in operation, the Fokker 27 (F-BYAO) of the 'Institut National de Sciences de l'Univers' (Chalon et al., 1998) and the Dornier 128 (D-IBUF) of the 'Universität Braunschweig' (Corsmeier et al., 2001). Intercomparison flights between the different aircraft were performed to achieve a high quality for the meteorological and air chemistry measurements (Saïd et al., 2004). During IOP 2b the Fokker 27 flew at a mean height of about $775 \mathrm{~m}$ MSL from 5:44 to 7:47 UTC and at a height of about $875 \mathrm{~m} \mathrm{MSL}$ between 11:00 and 12:05 UTC, while the Dornier 128 flew at a height of about $920 \mathrm{~m}$ MSL from 14:09 to 15:34 UTC. The flight patterns of the Fokker 27 and Dornier 128 are included in Figs. 11-13. A more detailed description of the whole experimental setup is given by Cros et al. (2004).

Table 1

Sites and abbreviations of the surface stations in the ESCOMPTE domain

\begin{tabular}{|c|c|c|}
\hline Measurements & Abbreviation and site & Abbreviation and site \\
\hline Radiosonde & RS1 St. Rémy & RS2 Vinon \\
\hline Ozone lidar & L1 Vallon Dol & L2 Cadarache \\
\hline Wind radar & R1 Aix les Milles & \\
\hline Sodar & SO1 Cadarache & \\
\hline \multirow[t]{13}{*}{ Wind data } & S1 Tarascon & S2 Arles \\
\hline & S3 Avignon & S4 La Crau \\
\hline & S5 Istres & S6 Port de Bouc \\
\hline & S7 Martigues & S8 La Gatasse \\
\hline & S9 Bonnieux & S10 Le Luberon \\
\hline & S11 La Barben & S12 La Fare les Oliviers \\
\hline & S13 Marignane & S14 Dupail \\
\hline & S15 Realtor & S16 Vitrolles \\
\hline & S17 Gardanne & S18 Vallon Dol \\
\hline & S19 Marseille & S20 Penne sur Huveaune \\
\hline & S21 St. Michel & S22 La Bastide \\
\hline & S23 Vinon & S24 Vauvenargues \\
\hline & S25 Ste. Baume & \\
\hline \multirow[t]{12}{*}{ Ozone data } & O1 Avignon & O2 Avignon \\
\hline & O3 Le Pontet & O4 St. Remy \\
\hline & O5 Fos sur Mer & O6 Miramas \\
\hline & O7 Martigues & O8 Berre 1'Etang \\
\hline & O9 Rognac & O10 Vitrolles \\
\hline & O11 Marignane & O12 Pennes Mirabeau \\
\hline & O13 Luberon & O14 Aix \\
\hline & O15 Aix & O16 Bouc Bel Air \\
\hline & O17 Plan de Cuques & O18 Marseilles \\
\hline & O19 St. Marguerite & O20 Penne sur Huveaune \\
\hline & O21 Aubagne & O22 Rousset \\
\hline & O23 Vinon & \\
\hline
\end{tabular}

The positions of the stations are given in Fig. 1. 

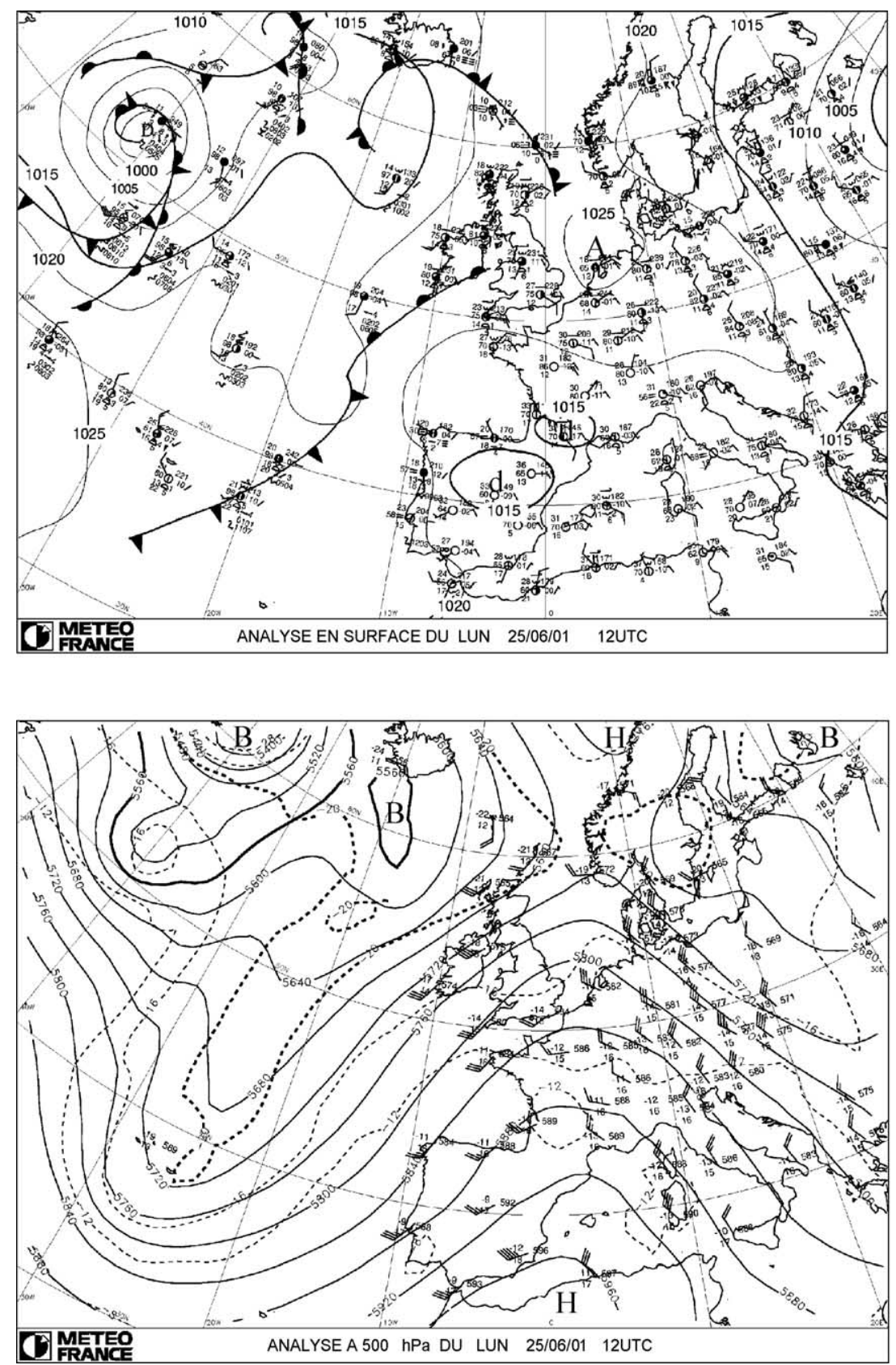

Fig. 2. (top) Surface pressure chart and (bottom) heights in gpm of the $500 \mathrm{hPa}$ isobars and temperature at 500 hPa on June 25, 2001, at 12 UTC. 


\subsection{Synoptic conditions}

On IOP $2 b$, the surface pressure over Europe is characterized by a high pressure system centred over the Netherlands (Fig. 2). Pressure gradients are low over the whole central Europe. This weather situation is accompanied by cloudless skies, high temperatures, low humidity, and weak synoptic winds. In the Durance valley (S23 in Fig. 1), the temperature nearly reaches $40{ }^{\circ} \mathrm{C}$. At $500 \mathrm{hPa}$, moderate westerly to northwesterly winds prevail over southern France (Fig. 2). These conditions favour both the evolution of mesoscale circulation systems and the evolution of a summer smog situation (Vogel et al., 1995; Vogel et al., 2000).

\section{PBL and surface wind field}

\subsection{Wind profiles in the $P B L$}

Continuous radiosoundings were performed to determine the temporal evolution and spatial distribution of the stable or nocturnal boundary layer (NBL) and the mixed or convective boundary layer $(\mathrm{CBL})$ in the investigation area, because the capping inversion at the CBL-top can be regarded as upper limit for vertical exchange processes. However, this is an assumption which is not always true over complex terrain, because processes like mountain venting and advective venting can lead to an exchange of trace gases between the PBL and the free troposphere (Koßmann et al., 1999).

Figs. 3, 4, and 5 show the vertical profiles in the Rhône valley at St. Rémy (RS1) and in the Durance valley at Vinon (RS2) on June 25, 2001, at 6, 12, and 15 UTC. In the Rhône valley at $6 \mathrm{UTC}$, a surface inversion of about $10 \mathrm{~K}$ has formed (Fig. 3) which extends up to $750 \mathrm{~m}$ above mean sea level (MSL). In this stable boundary layer, the specific humidity is about $11 \mathrm{~g} \mathrm{~kg}^{-1}$ and decreases to $7 \mathrm{~g} \mathrm{~kg}^{-1}$ above. Wind speed is low from east. These easterly winds also occur at Vinon and further south, as obvious from the aircraft measurements discussed in Section 4 (Fig. 11). At St. Rémy between 750 and $1750 \mathrm{~m}$ MSL, the wind speed remains low with values of about $2-3 \mathrm{~m} \mathrm{~s}^{-1}$. Above that layer, the wind direction turns to northwest and wind speed increases continuously with height, reaching values of about $13 \mathrm{~m} \mathrm{~s}^{-1}$, i.e., it corresponds to the synoptic wind data (Fig. 2). Similar upper level winds appear at Vinon. However, within the NBL, which extends up to $1 \mathrm{~km}$ MSL, northeasterly to easterly winds occur, accompanied by a jet-like wind speed profile. The jet reaches about $8 \mathrm{~m} \mathrm{~s}^{-1}$ at $750 \mathrm{~m} \mathrm{MSL}$. These northeasterly winds agree with the orientation of the Durance valley and indicate the nocturnal down-valley wind system. The jet can also be observed in the sodar measurements performed at Cadarache (SO1). It develops at about 2 UTC and reaches its maximum at about 6 UTC (Fig. 6). The jet-like profile of the down-valley wind system within the NBL is a well-known phenomenon from other investigations (Whiteman, 2000). The sodar measurements also reveal the change from the nocturnal down-valley wind system to the daytime up-valley wind system which establishes at about 9 UTC.

In St. Rémy at 12 UTC, a well-defined mixed layer has developed up to $1 \mathrm{~km} \mathrm{MSL}$, capped by an inversion of about $3 \mathrm{~K}$ (Fig. 4). The mixed layer top can also be identified by 

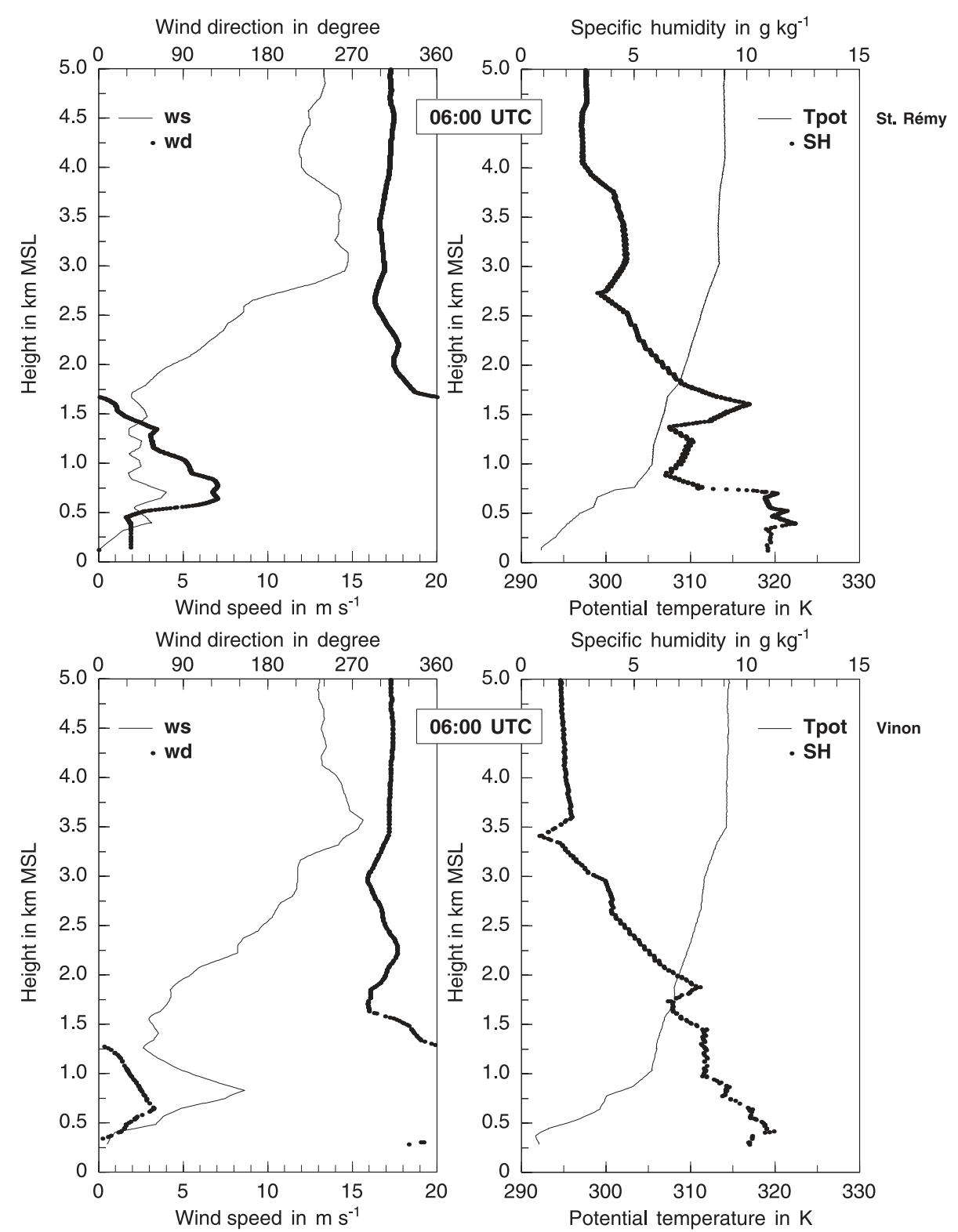

Fig. 3. Profiles of wind speed (ws), wind direction (wd), potential temperature (Tpot), and specific humidity (SH) at 6 UTC for St. Rémy (RS1) (top) and Vinon (RS2) (bottom).

the specific humidity profile which decreases from about 10 to $7 \mathrm{~g} \mathrm{~kg}^{-1}$. Within the mixed layer, a weak southerly valley wind of $2-3 \mathrm{~m} \mathrm{~s}^{-1}$ has established, while the northwesterly synoptic flow prevails above. In Vinon, the top of the mixed layer is found at about 1800 $\mathrm{m}$ MSL. Within this layer, a southwesterly valley wind is observed, as already obvious 

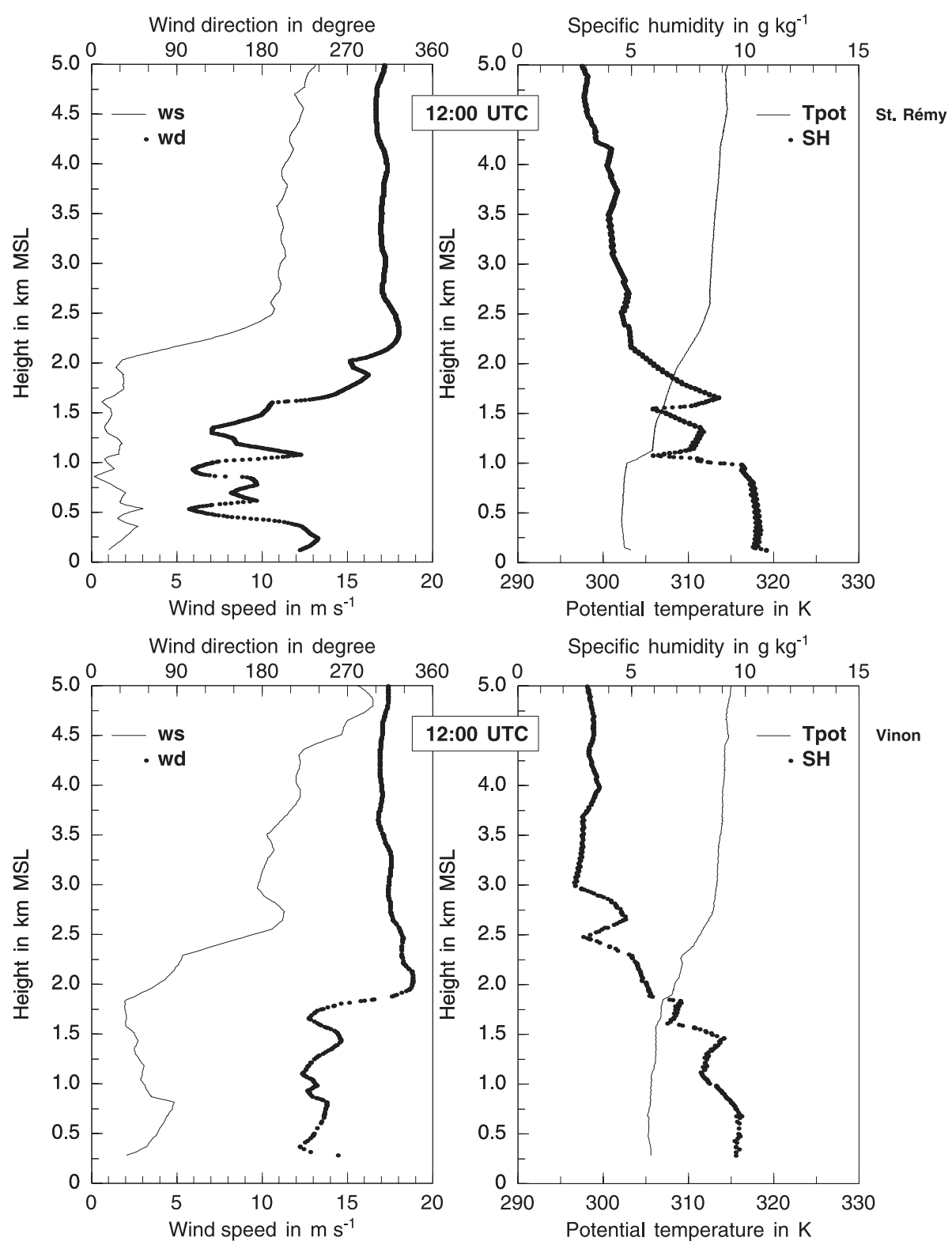

Specific humidity in $\mathrm{g} \mathrm{kg}^{-1}$

Fig. 4. Same as Fig. 3, but for 12 UTC.

from the sodar data (Fig. 6). A veering of the wind direction from southwesterly valley to northwesterly synoptic winds appears at the top of the mixed layer. The different valley wind regimes can also be detected from the Fokker 27 flight performed at $875 \mathrm{~m}$ MSL from 11:00 and 12:05 UTC, although the different regimes seem less pronounced in the aircraft data (Fig. 12). 

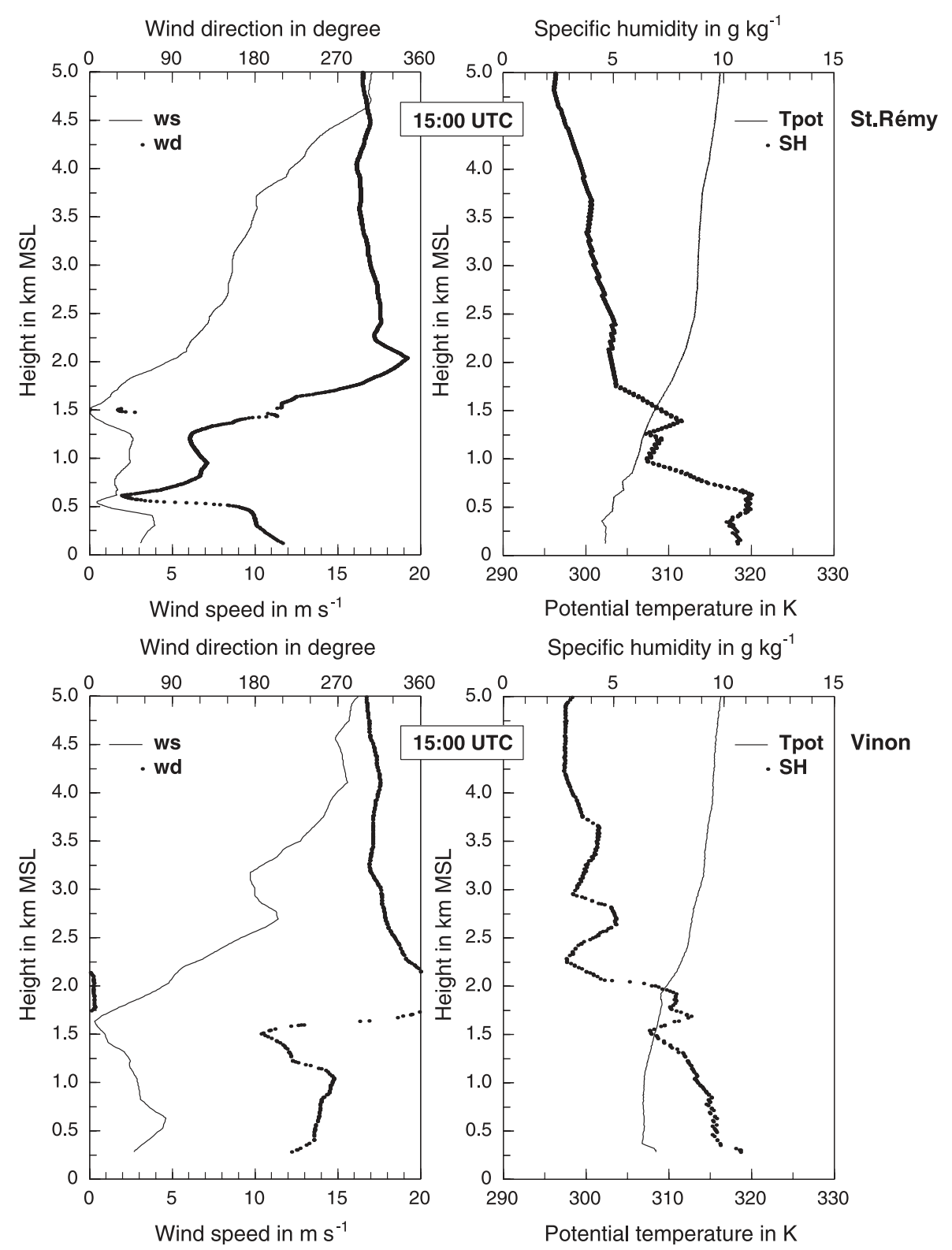

Fig. 5. Same as Fig. 3, but for 15 UTC.

Three hours later (Fig. 5) in Vinon conditions are nearly unchanged, while in the Rhône valley at St. Rémy, the mixed layer top has decreased significantly from $1 \mathrm{~km}$ to $400 \mathrm{~m}$ MSL. Obviously, the reduction of the mixed layer top at St. Rémy results because the potential temperature remains at $\theta \approx 302 \mathrm{~K}$ (i.e., $((\partial \Theta) /(\partial t)) \approx 0$ ) up to $400 \mathrm{~m}$ MSL, while the potential temperature increases by $((\partial \Theta) /(\partial t)) \approx 1 \mathrm{~K} \mathrm{~h}^{-1}$ between $400 \mathrm{~m}$ MSL and 2.5 


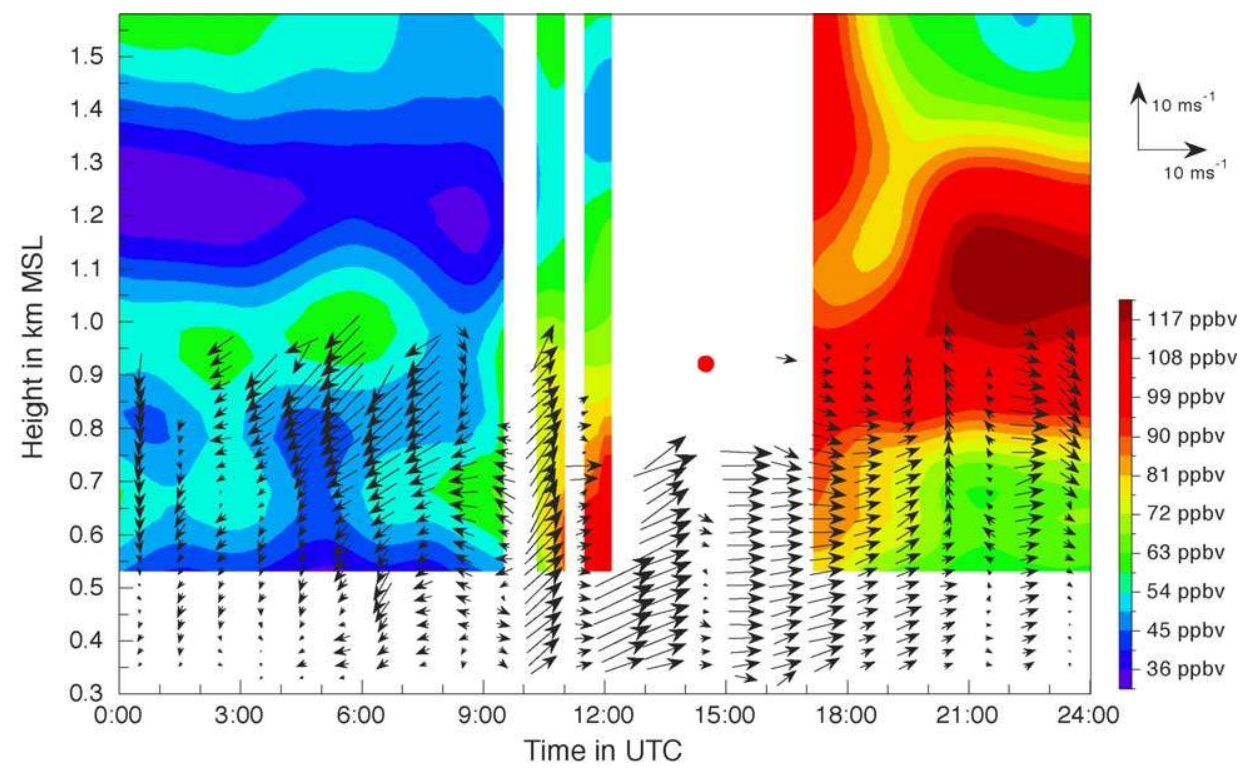

Fig. 6. Horizontal wind vectors measured by sodar (SO1) and ozone concentrations measured by lidar (L2) at Cadarache on June 25, 2001. The red dot indicates the ozone value measured by the Dornier 128 over the Cadarache site.

$\mathrm{km}$ MSL. As from the divergence of the sensible heat flux $\left(H_{\mathrm{o}}\right.$ is about $200 \mathrm{~W} \mathrm{~m} \mathrm{~m}^{-2}$ at Vinon between 12 and 15 UTC), a mixed-layer heating of about $1 \mathrm{~K} \mathrm{~h}^{-1}$ can be expected. This heating must have been compensated by advection of cold air with the sea breeze system, to achieve the nearly observed stationary conditions:

$$
-\frac{1}{\rho c_{p}} \frac{\partial H}{\partial z}-v \frac{\partial \Theta}{\partial y}-u \frac{\partial \Theta}{\partial x} \approx 0
$$

$\rho$ denotes the air density, $c_{p}$ the specific heat at constant pressure, and $u$ and $v$ are the $x$ and $y$-component of the horizontal wind vector. So it can be concluded that the sea breeze front passes St. Rémy between 12 and 15 UTC, although no significant increase in humidity can be detected during that period. The northward penetration of the sea breeze front in the Rhône valley was also observed and modelled with MesoNH-C for the day before (June 24, 2001) by Cousin et al. (2004). They fixed the passage of the sea breeze front at Avignon (O1) to 13 UTC. The passage of the sea breeze front is also accompanied by nearly stationary temperature conditions during the subsequent hours. Abrupt changes of the CBL top caused by cold air advection have already been described by other investigators (e.g., Oke, 1987; Koßmann et al., 1998; Kalthoff et al., 1999). As the sea breeze superimposes the valley wind system, an increase of the wind speed by about $2 \mathrm{~m}$ $\mathrm{s}^{-1}$ can be detected from 12 to 15 UTC. A similar behaviour can be observed between 12 and 13 UTC at Crau (S4) which is situated more south of the Rhône valley (Fig. 10). Between $400 \mathrm{~m}$ and $1500 \mathrm{~m}$ MSL, a layer with easterly winds establishes (Fig. 5), which is also obvious from the aircraft data recorded between 14:09 and 15:34 UTC at about $920 \mathrm{~m}$ 
MSL (Fig. 13). These easterly winds are of relevance for the horizontal transport of ozone as discussed in Section 4.

To sum up, it can be stated that the morning flight at about $775 \mathrm{~m}$ MSL was performed in the transition zone between the top of the NBL and the residual layer, while the noon flight at about $875 \mathrm{~m}$ MSL was performed within the mixed layer. The afternoon flight at about $920 \mathrm{~m}$ MSL took place within the mixed layer in the eastern part of the domain, but above the mixed layer in the Rhône valley.

\subsection{The surface wind field}

An overview of the surface wind field on IOP $2 \mathrm{~b}$ is given by plotting the wind vectors for time periods when the conditions are nearly stationary (Figs. 7-9). Additionally, the diurnal cycles of wind speed and wind direction are shown for selected sites, i.e., on the coast, in the Rhône valley, and in the Durance valley (Fig. 10).

At night ( $0-5$ UTC), the surface wind field is dominated by local effects and, therefore, reveals a very heterogeneous structure (Fig. 7), as typical for complex terrain (e.g., Melas et al., 1998; Koßmann and Fiedler, 2000). At stations in the Rhône valley (S1, S2, S4), down-valley winds have established, while in the city of Marseille (S18, S19) a land breeze can be detected. At the lake Etang de Berre, a land breeze system has developed with a southerly flow at Marignane (S13) and northerly flow at Istres (S5). At stations on

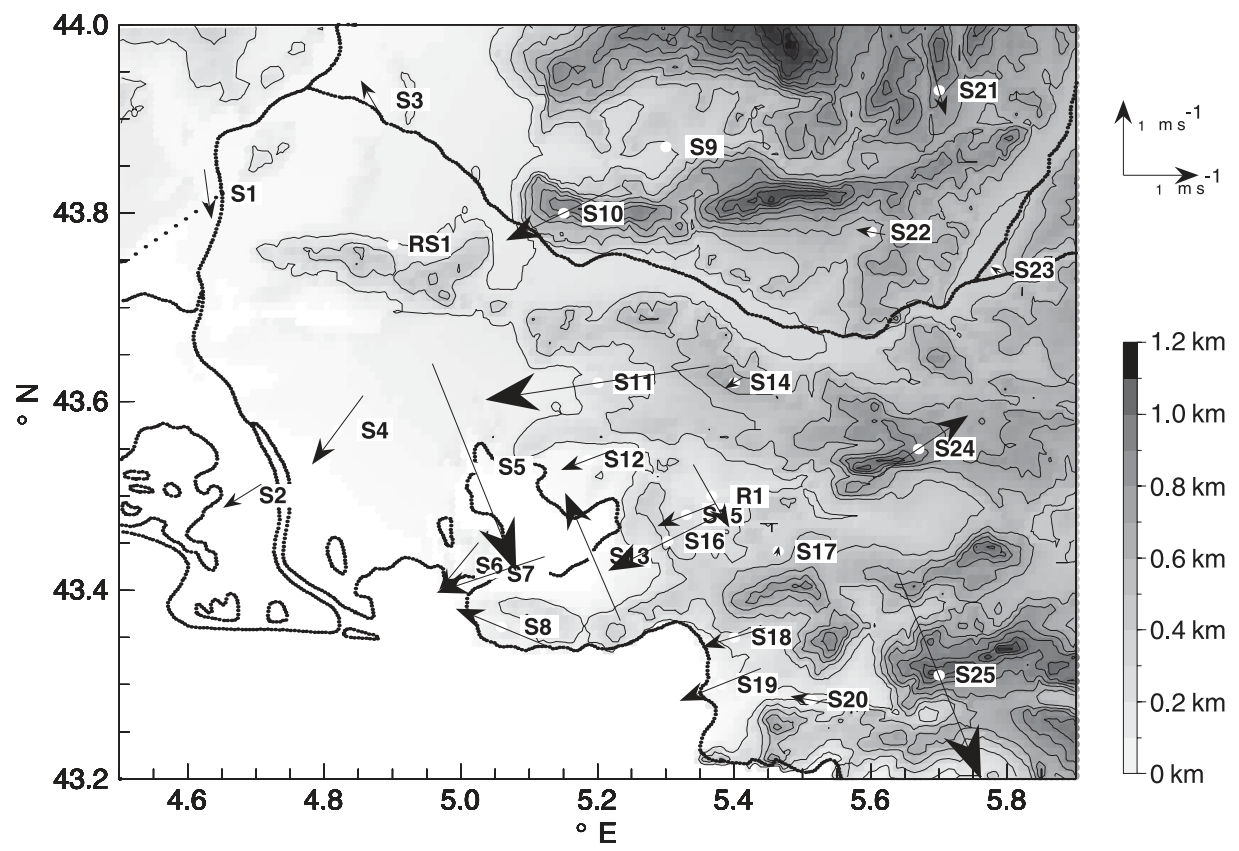

Fig. 7. Characteristic surface wind field on June 25, 2001, between 0 and 5 UTC. The grey scale indicates the height of orography. 


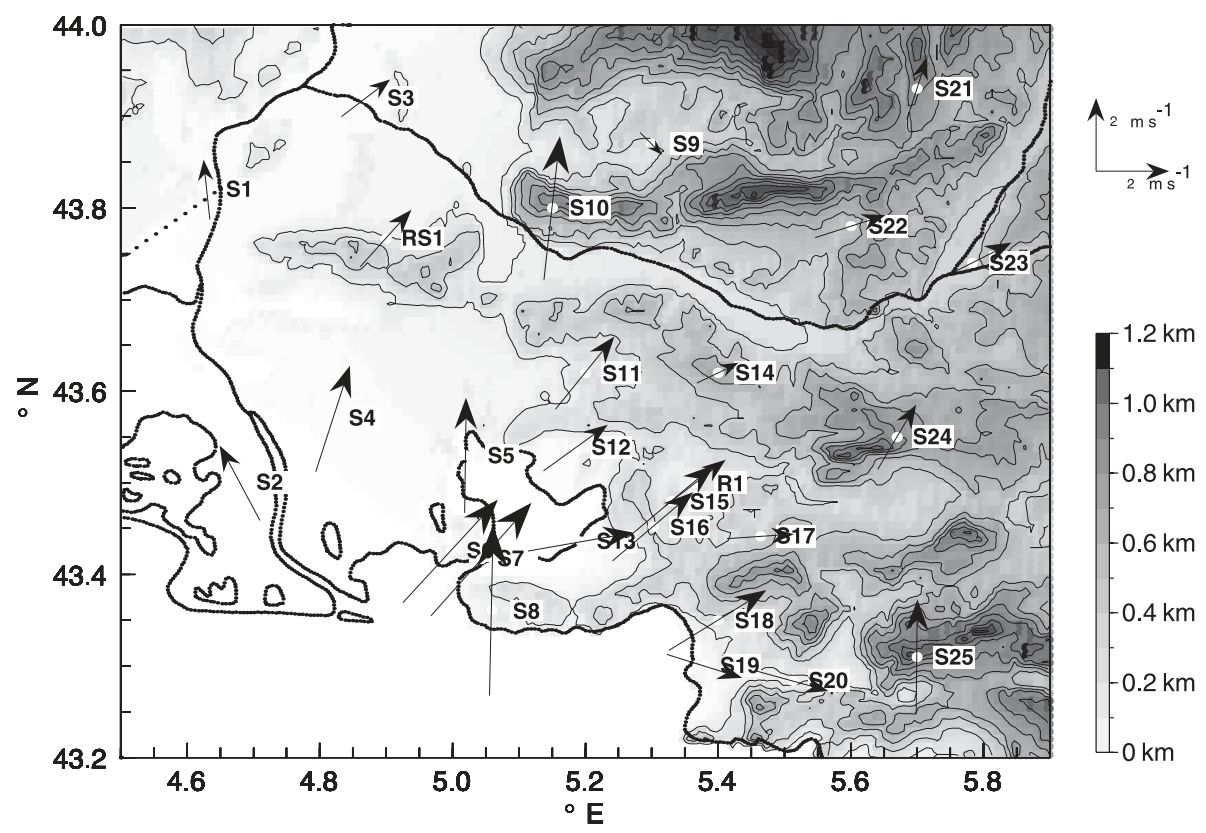

Fig. 8. Same as Fig. 7, but for the time interval from 9 to 14 UTC.

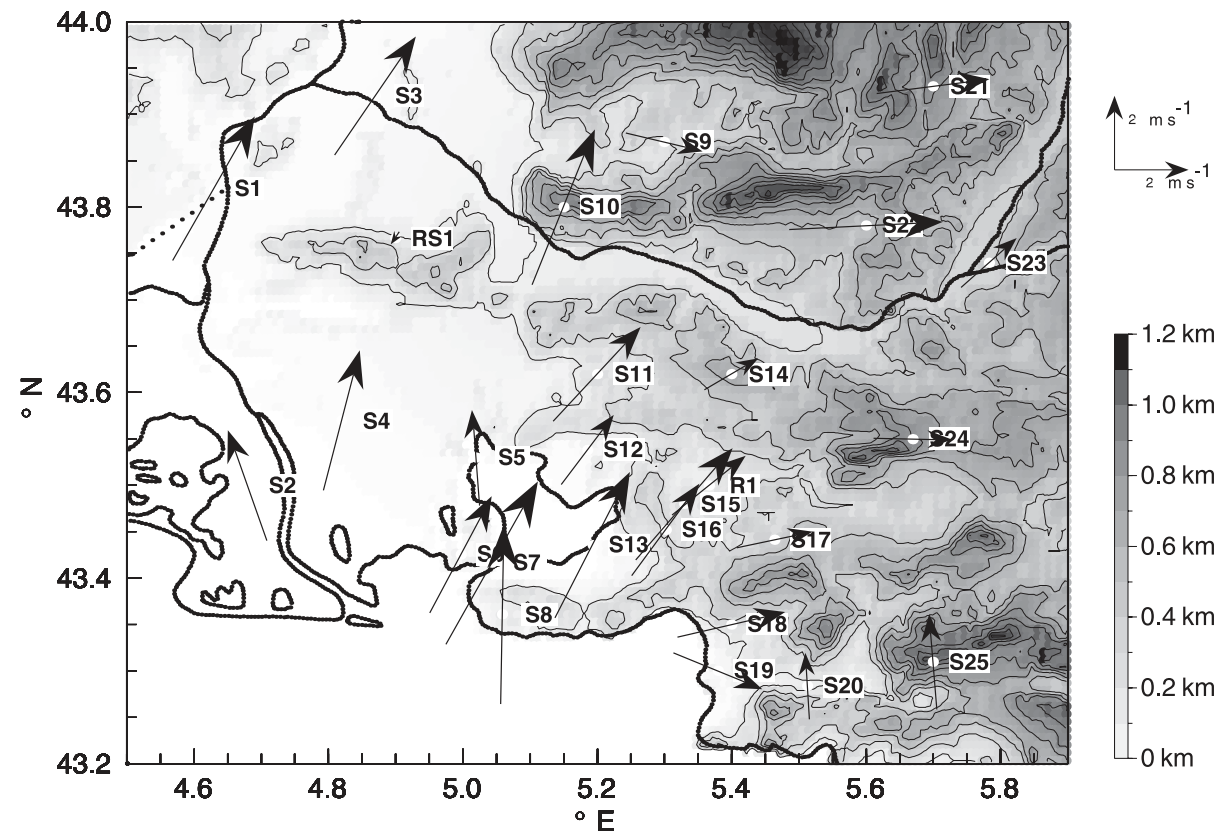

Fig. 9. Same as Fig. 7, but for the time interval from 14 to 19 UTC. 

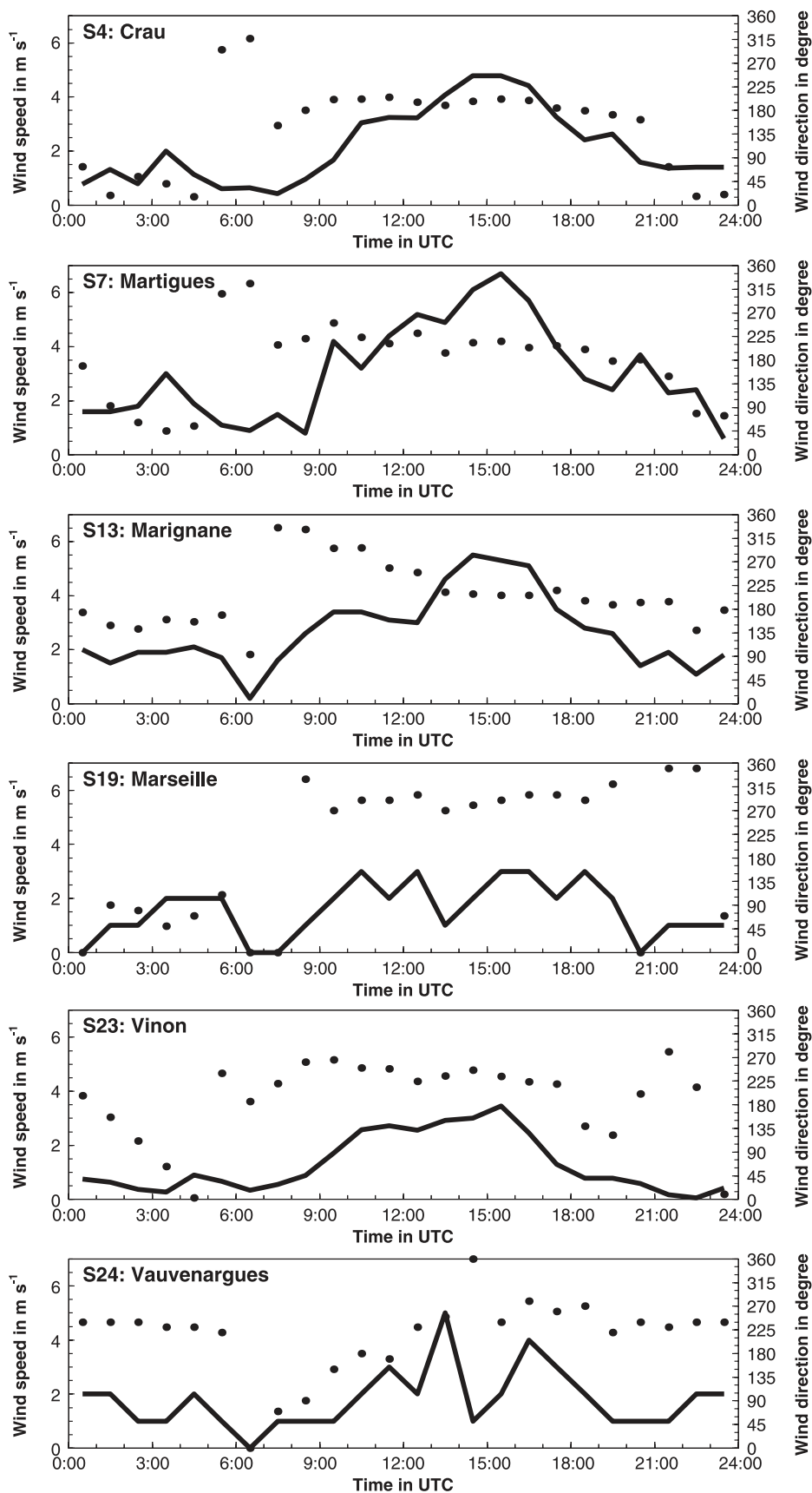

Fig. 10. Time series of wind speed (solid line) and wind direction (dots) at different surface stations. The positions of the stations are indicated in Fig. 1. 
slopes, drainage winds occur, which are directed to the valley ground (e.g., S10, S21, S25). During the night, winds are generally low, i.e., $<2 \mathrm{~m} \mathrm{~s}^{-1}$.

The change from nocturnal conditions to the daytime wind regime takes place between 5 and 8 UTC (Fig. 10). Between 9 and 14 UTC (Fig. 8), the surface wind field is characterised by southerly up-valley winds in the Rhône valley (S3, S4), southwesterly winds in the area of lake Etang de Berre and Marseille, while an up-valley wind system has developed in the Durance valley (S23). Thus, the wind field during this period is more homogeneous than during the night and local orographic structures are of minor relevance. Additionally, wind speeds are much higher than during night.

In the afternoon (14-19 UTC), the general structure of the surface wind field (Fig. 9) is similar to that of the hours around noon. However, the up-valley wind in the Rhone valley has strengthened, as is also obvious from the diurnal cycle of the wind speed at Crau (S4) in Fig. 10.

Summarizing the meteorological conditions on IOP $2 b$, it can be stated that

- During the night, the wind field is dominated by local conditions, resulting in drainage flows on the slopes, down-valley winds, and a land breeze at lake Etang de Berre. The surface wind speeds are low $\left(<2 \mathrm{~m} \mathrm{~s}^{-1}\right)$.

- The nocturnal down-valley wind system in the Durance valley has a vertical extension of about $1 \mathrm{~km}$. The wind profile reveals a jet-like structure with a maximum of $8 \mathrm{~m} \mathrm{~s}^{-1}$ just below the top of the NBL.

- The nocturnal surface wind regime has been replaced completely by the daytime surface wind regime at about 9 UTC. At 12 UTC, the top of the well-mixed layer can be found at $1 \mathrm{~km}$ MSL in the Rhône valley and at $1.8 \mathrm{~km}$ MSL in the Durance valley.

- Between 12 and 15 UTC, the temperature profile in the Rhône valley about $50 \mathrm{~km}$ inland indicates the passage of the sea breeze front, resulting in a decrease of the mixed layer capping inversion from $1 \mathrm{~km}$ MSL down to $400 \mathrm{~m}$ MSL. As the up-valley wind and sea breeze wind superimpose in the Rhône valley, the wind speed increases in the afternoon.

The impact of these different flow regimes on the ozone distribution shall be discussed in the next section.

\section{Spatial distribution and temporal evolution of ozone}

\subsection{Ozone distribution at the surface stations and on the flight legs}

Ozone distribution is analysed by means of the surface stations (Fig. 1; Table 1) and the aircraft measurements, i.e., the Fokker 27 flight in the morning (5:44-6:44 UTC at about $775 \mathrm{~m} \mathrm{MSL}$ ) and the flight around noon (11:00-12:05 UTC at about $875 \mathrm{~m} \mathrm{MSL)}$ and the Dornier 128 flight in the afternoon (14:09-15:35 UTC at about $920 \mathrm{~m} \mathrm{MSL}$ ). Original ozone and meteorological data were low-pass filtered with a cut-off length of $12.5 \mathrm{~km}$. This cut-off length corresponds with the distance between two parallel flight legs and allows a reasonable interpolation of the data, i.e., ozone structures in the 
interpolated data field in both directions (parallel and perpendicular to the flight legs) are of the same scale. The surface data in the subsequent diagrams were averaged over the time period of the corresponding aircraft flights. Resulting ozone concentrations and horizontal wind vectors on the different flight legs and the ozone concentrations at the surface stations are given in Figs. 11-13. Fig. 14 presents diurnal cycles of ozone concentration for selected sites. A complete overview for all stations is given by Thürauf (2002).

In the morning between 5:44 and 6:44 UTC, all surface stations positioned at low altitudes indicate ozone concentrations below 20 ppbv (Figs. 11 and 14), caused by chemical transformation and as ozone is deposited on the ground during night. The profile flight performed by Fokker 27 at Avignon (O1) at 5:27 UTC reveals an increase in ozone concentration from surface values of about $15 \mathrm{ppbv}$ to values of about $60 \mathrm{ppbv}$ in the residual layer at $900 \mathrm{~m}$ MSL (Fig. 15). An increase from low surface values to the background concentrations in the residual layer is a typical profile also observed by other investigators (Corsmeier et al., 1997; Güsten et al., 1998). These high background concentrations of $60 \mathrm{ppbv}$ were also measured by the Luberon mountain station at $675 \mathrm{~m}$ MSL (O13) and reflect conditions typical for many mountain sites (Fiedler and Borrell, 2000; Gallardo et al., 2000; Donev et al., 2002). At Luberon, the ozone concentration is nearly constant during the night (Fig. 14). The aircraft measurements, performed in the transition zone between the top of

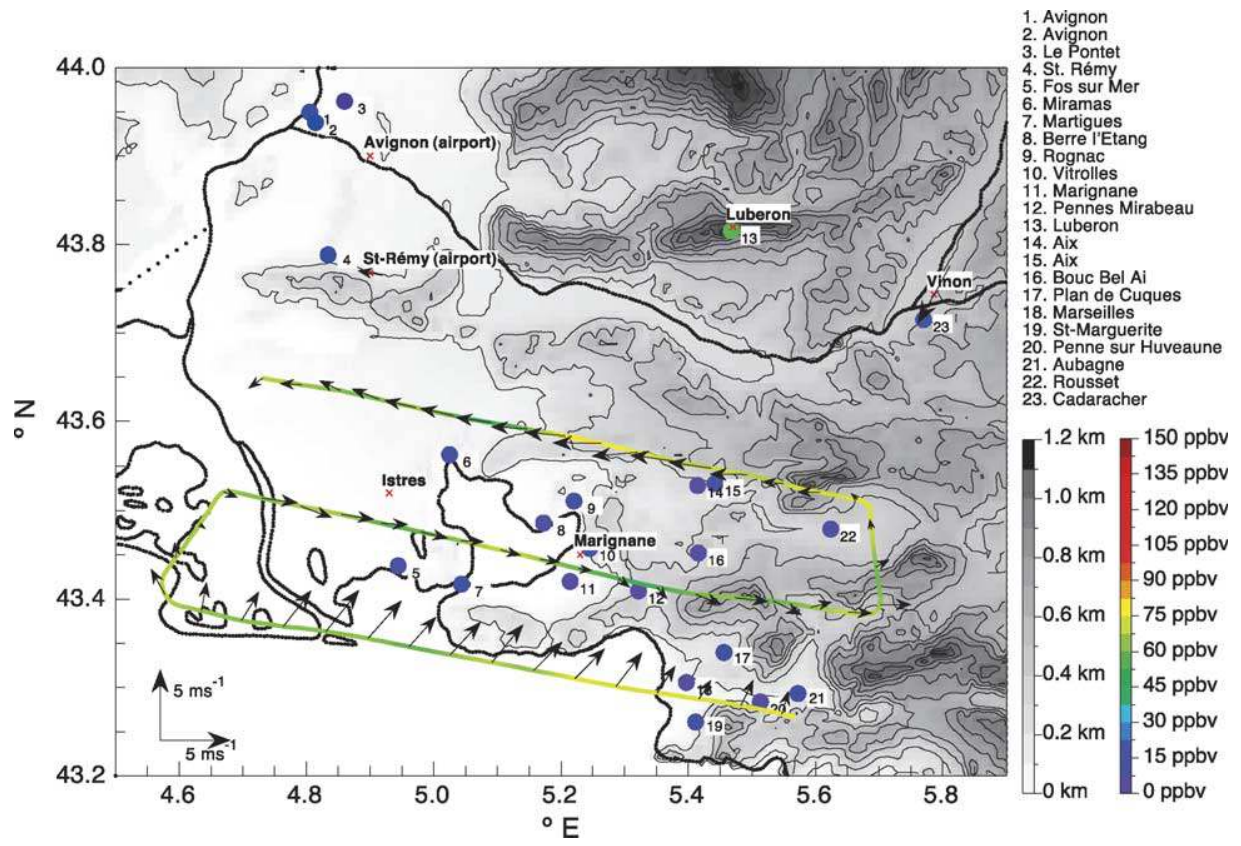

Fig. 11. Ozone concentration and wind vectors along the horizontal flight legs of Fokker 27 at about $775 \mathrm{~m}$ MSL on June 25,2001, between 5:44 and 6:44 UTC. The dots indicate the ozone concentrations at the surface stations averaged over the corresponding flight period. 


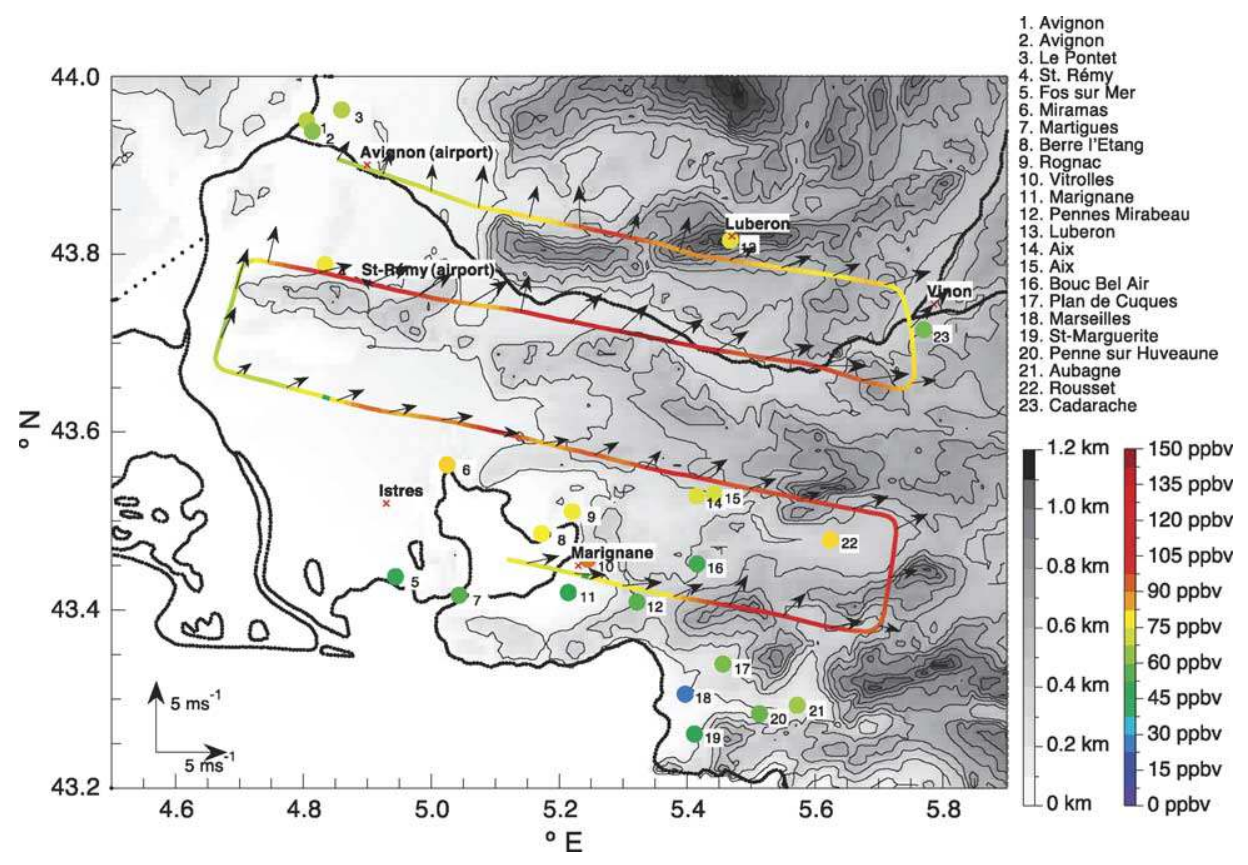

Fig. 12. Ozone concentration and wind vectors along the horizontal flight legs of Fokker 27 at about $875 \mathrm{~m}$ MSL on June 25, 2001, between 11:00 and 12:05 UTC. The dots indicate the ozone concentrations at the surface stations averaged over the corresponding flight period.

the NBL and the residual layer at about $775 \mathrm{~m}$ MSL between 5:44 and 6:44 UTC, indicate that the concentrations vary between 40 and $80 \mathrm{ppbv}$ in the whole investigation area (Fig. 11).

When the surface inversion erodes between 6 and 9 UTC, ozone is mixed downward from the residual layer into the developing CBL. Beside photochemical production this vertical mixing mainly causes the daily surface ozone maximum (Fiedler and Borrell, 2000). Consequently, the ozone concentrations increase from values below 20 ppbv to 60 ppbv, i.e., to the background concentrations, at the coastal sites of Martigues (O7) and Marignane (O11), which are influenced at this time by the sea breeze system rather than by the Marseille city plume. At both sites, the concentrations do not exceed this background concentration during the rest of the day because of missing ozone precursors (Fig. 14). At all other stations which are also affected by photochemical ozone production and horizontal transport, ozone concentrations further increase until afternoon (Fig. 14). During noon, flight ozone concentrations of up to $80 \mathrm{ppbv}$ can be found at surface stations in the lee of Marseille (Fig. 12). Even higher values of up to $150 \mathrm{ppbv}$ are observed in the upper mixed layer at $875 \mathrm{~m}$ MSL north, northeast, and east of Marseille. So, it can be concluded that effective vertical mixing of the ozone precursors $\mathrm{NO}_{2}$ and VOC as well as photochemical ozone production have occurred in the whole mixed layer. Ozone concentrations in the Rhône valley at $875 \mathrm{~m}$ MSL are significantly lower (about 60 ppbv). Between 11 and 12 UTC, the ozone concentration at Luberon (O13) increases from 


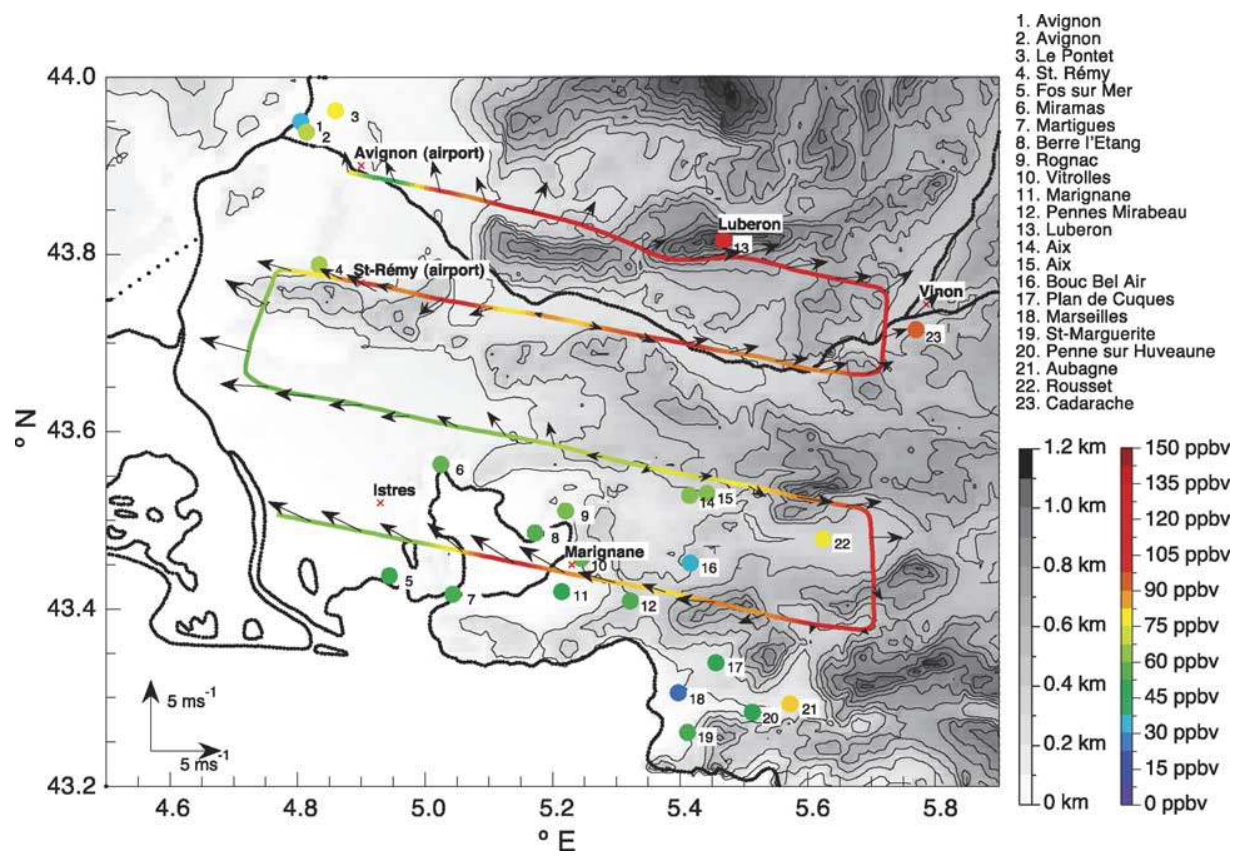

Fig. 13. Ozone concentration and wind vectors along the horizontal flight legs of Dornier 128 at about $920 \mathrm{~m}$ MSL on June 25, 2001, between 14:09 and 15:34 UTC. The dots indicate the ozone concentrations at the surface stations averaged over the corresponding flight period.

about 60 to more than 100 ppbv (Fig. 14). This is due to the fact that the top of the mixed layer surpasses the elevation of the measurement site (Fig. 4) so that polluted air can reach the mountain site by horizontal advection from the south. This phenomenon is often observed at stations on mountains of medium altitude (Volz-Thomas et al., 2000; Fiedler and Borrell, 2000), i.e., they are influenced by CBL growth, slope winds, or valley winds. The role of horizontal advection for the local change of ozone shall be discussed in the following section.

In the afternoon, the highest ozone concentrations of about $120 \mathrm{ppbv}$ can be found about $50 \mathrm{~km}$ further downwind north and northeast of Marseille both on the ground (Vinon, Luberon) and on the flight level of $920 \mathrm{~m} \mathrm{MSL} \mathrm{(Fig.} \mathrm{13).}$

\subsection{Interpolation algorithm and calculation of ozone advection}

Local change of ozone may result from different processes, including horizontal advection, vertical advection, turbulent diffusion, chemical transformation and deposition (Corsmeier et al., 2000). Ozone concentration and wind fields on a horizontal plane can be used to determine the contribution of horizontal advection to local change. To calculate ozone advection on the flight levels, two approaches have been applied. First, an interpolation algorithm, the Kriging technique (Matheron, 1963; Matheron, 1989), is applied to obtain meteorological and ozone data on a fixed grid. 

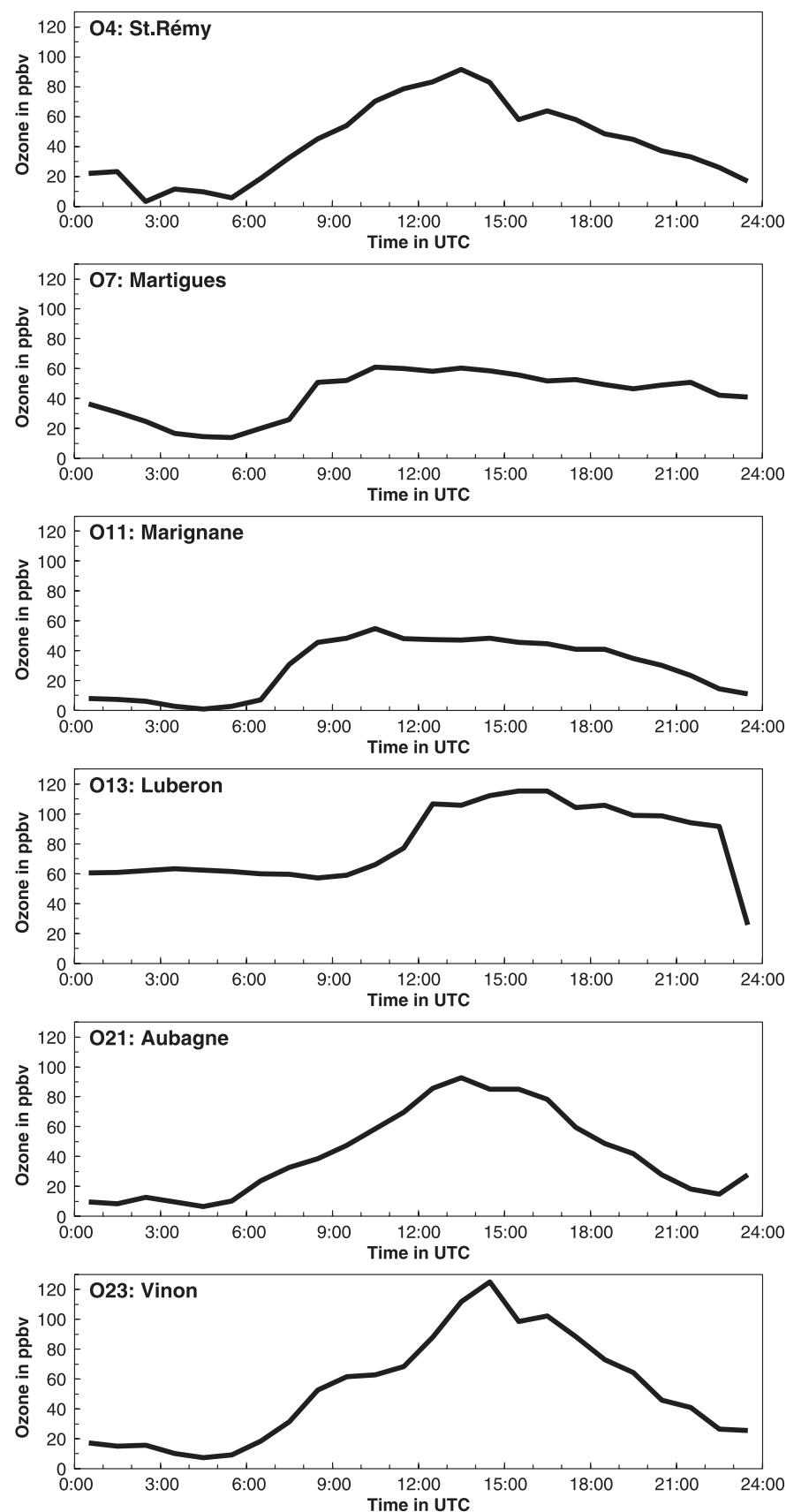

Fig. 14. Diurnal cycles of ozone concentrations at selected sites. The positions of the surface stations are indicated in Fig. 1. 


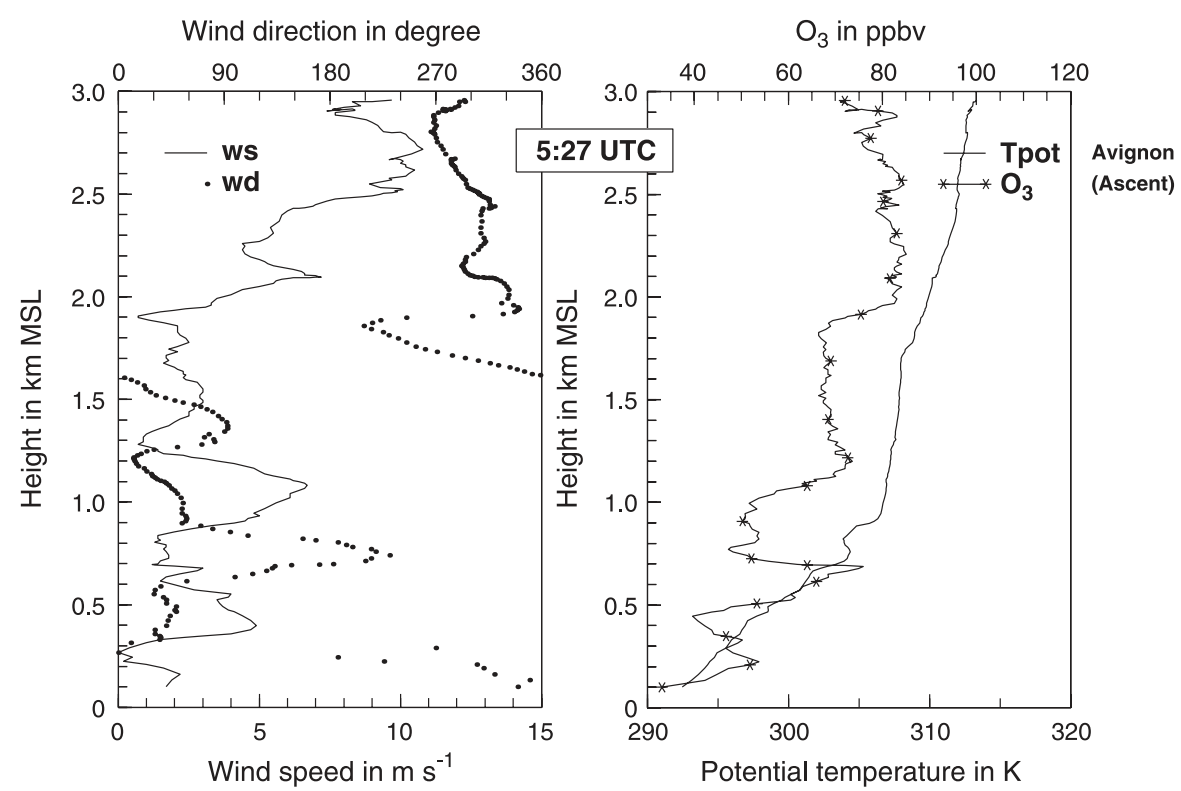

Fig. 15. Profiles of wind speed (ws), wind direction (wd), potential temperature (Tpot), and Ozone $\left(\mathrm{O}_{3}\right)$ at $5: 27$ UTC of Fokker 27 from the profile flight at Avignon (O1).

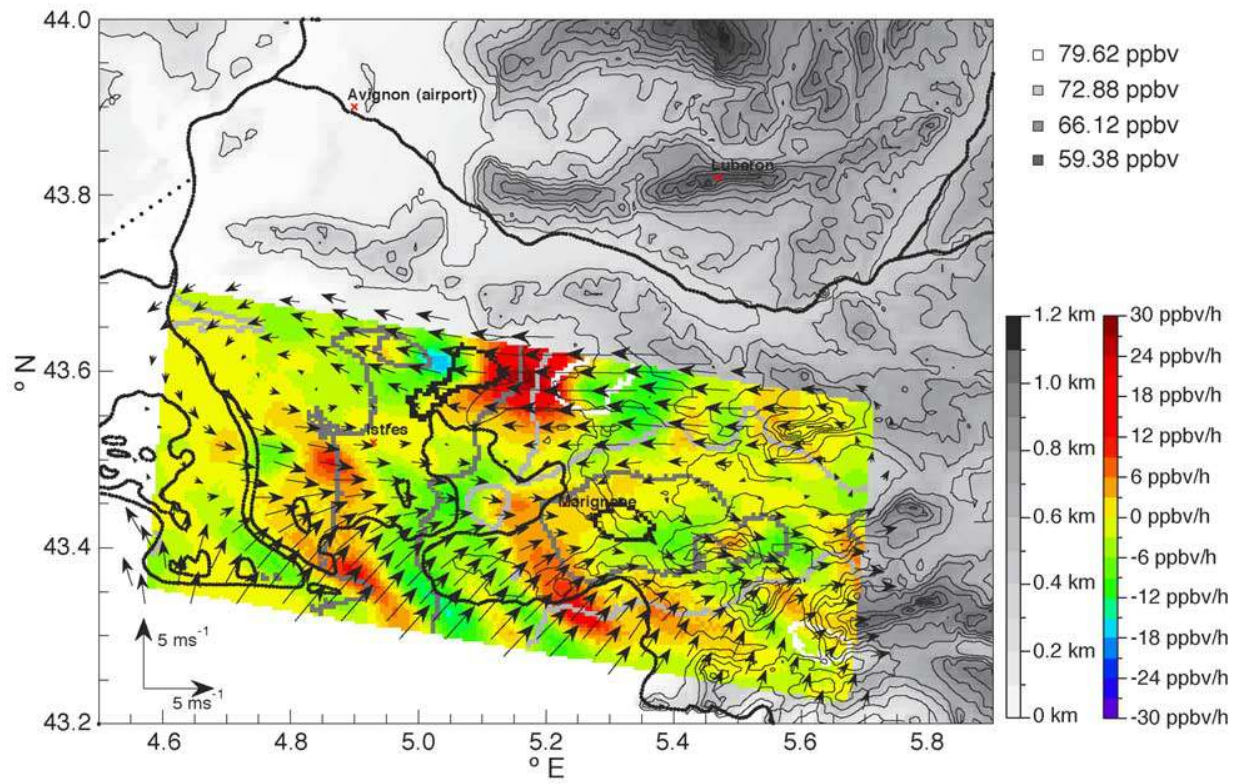

Fig. 16. Horizontal advection of ozone (coloured scale), horizontal wind vectors, and isolines of ozone concentrations (white, grey and black isolines, see upper scale) on June 25, 2001, from 5:44 to 6:44 at about 775 $\mathrm{m}$ MSL. 


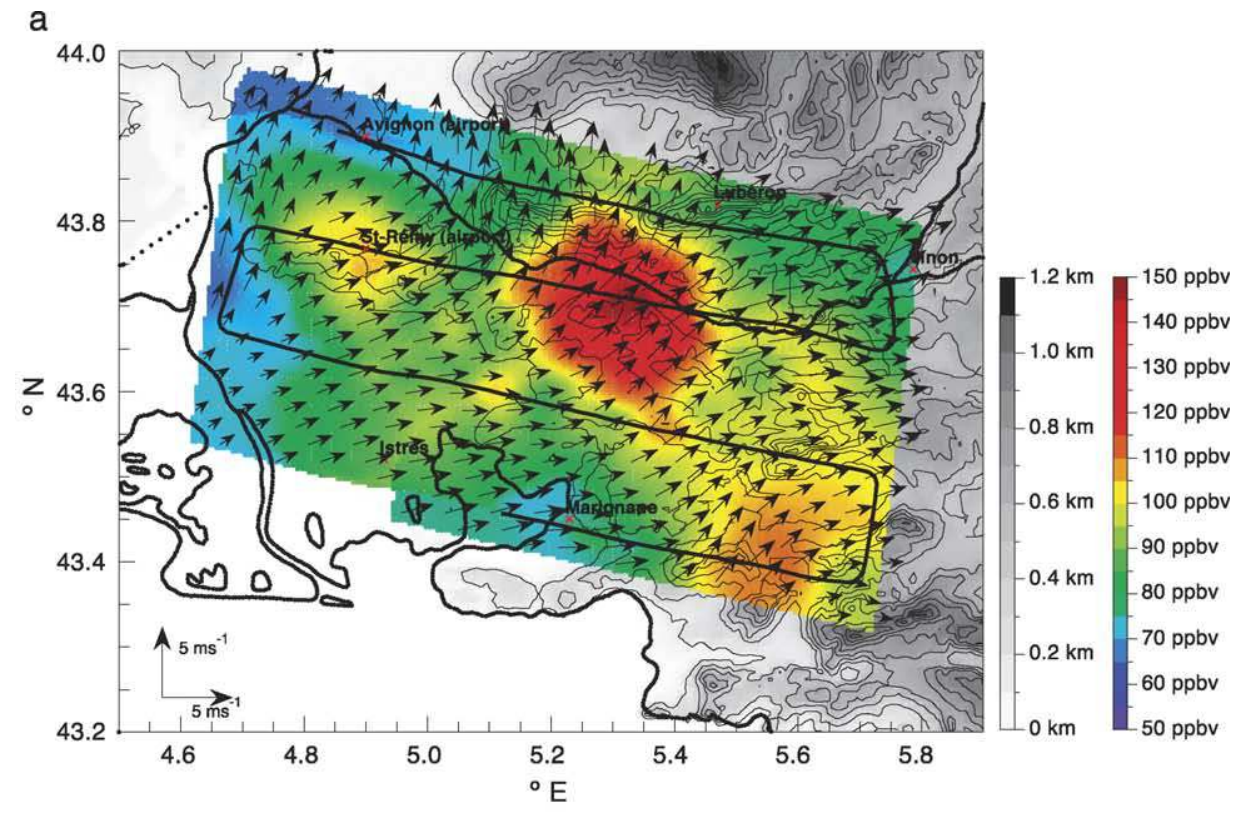

b

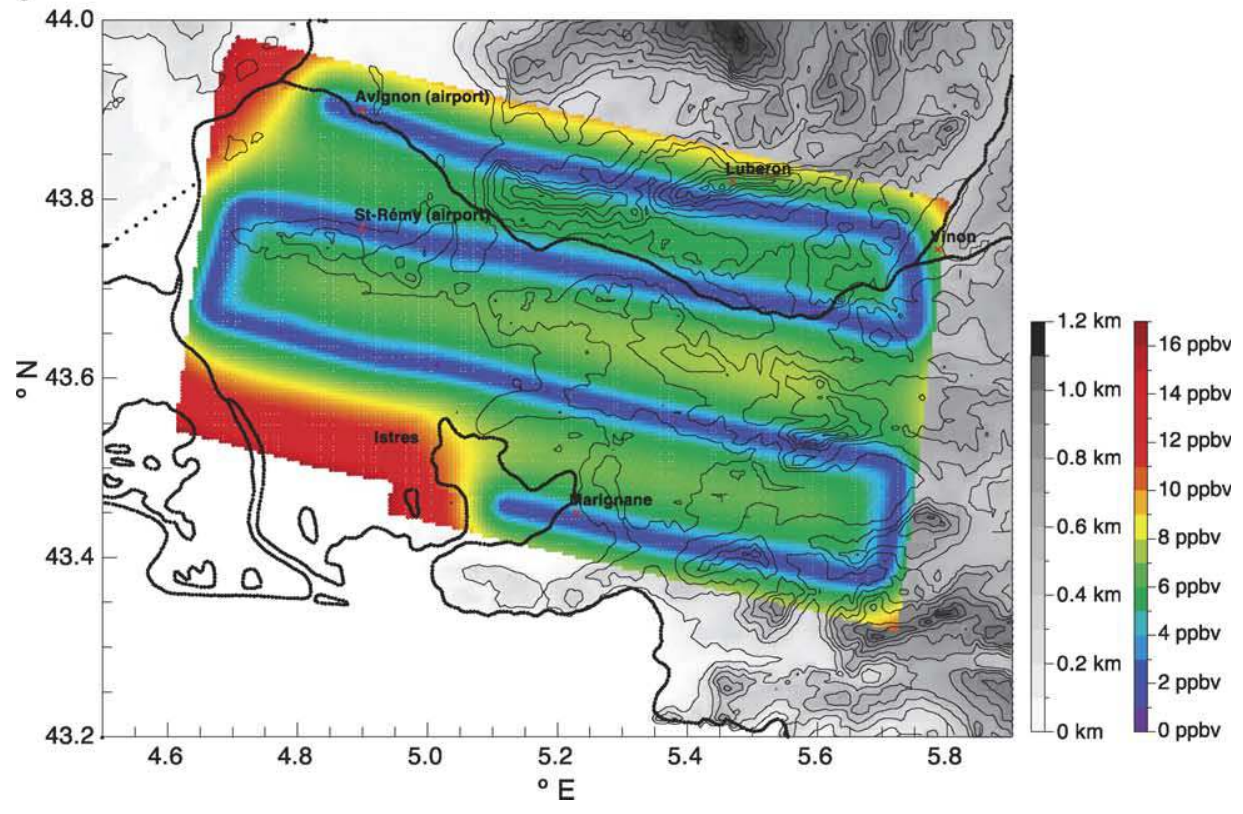

Fig. 17. (a) Interpolated ozone distribution and horizontal wind vectors at $875 \mathrm{~m}$ MSL on June 25, 2001, from 11:00 to 12:05 UTC. (b) Standard deviation of the calculated ozone concentrations on June 25, 2001, from 11:00 to 12:05 UTC. (c) Horizontal advection of ozone (coloured scale), horizontal wind vectors, and isolines of ozone concentrations (white, grey and black isolines, see upper scale) on June 25, 2001, from 11:00 to 12:05 at about 875 m MSL. 


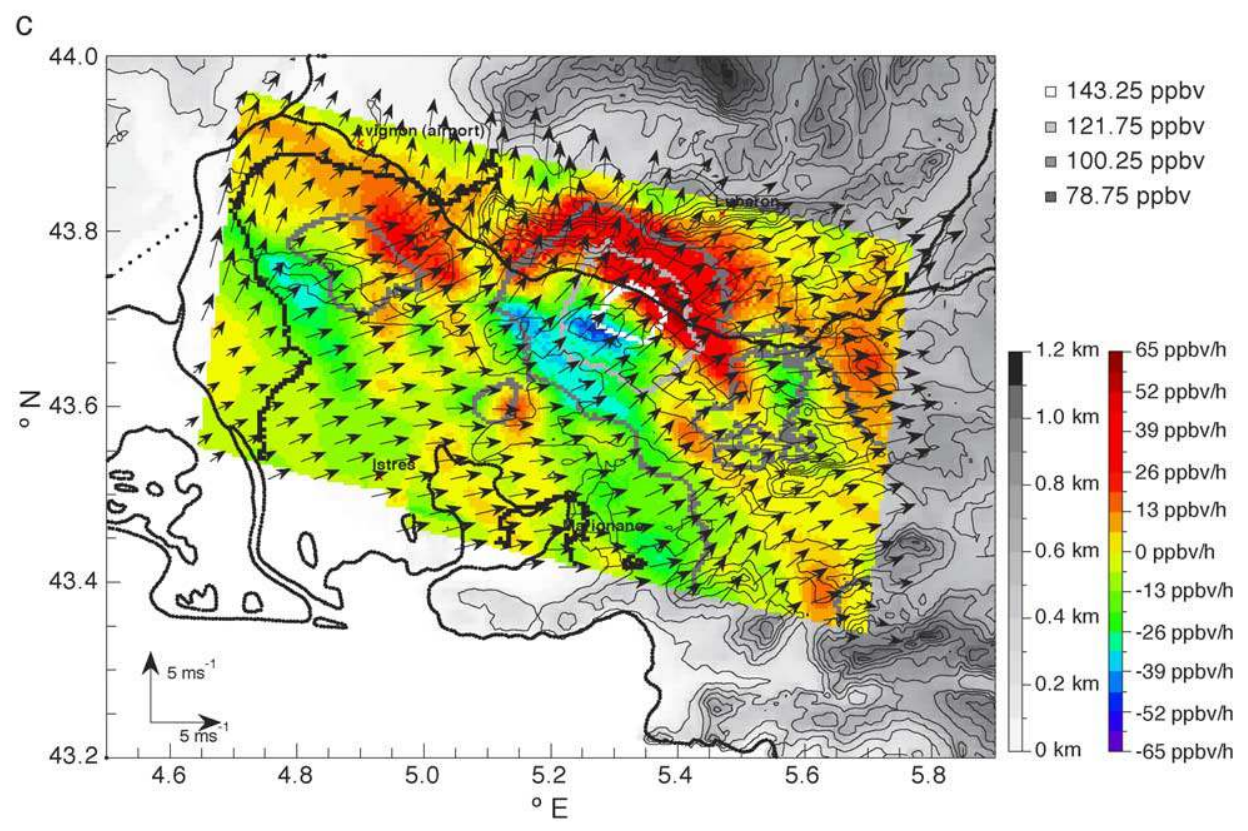

Fig. 17 (continued).

Then, the interpolated fields are used to calculate the horizontal advection of ozone according to:

$$
u \frac{\partial \mathrm{O}_{3}}{\partial x}+v \frac{\partial \mathrm{O}_{3}}{\partial y}=u_{(0)} \frac{\mathrm{O}_{3(1)}-\mathrm{O}_{3(-1)}}{2 \Delta x}+v_{(0)} \frac{\mathrm{O}_{3(1)}-\mathrm{O}_{3(-1)}}{2 \Delta y}
$$

where $u_{(0)}$ and $v_{(0)}$ define the $u$ and $v$ components of the horizontal wind speed vector at the specific grid point of interest and $\mathrm{O}_{3(1)}$ and $\mathrm{O}_{3(-1)}$ are the ozone concentrations at the neighbouring grid points (previous and next) at the same time. $\Delta x$ and $\Delta y$ are the mesh widths of the grid in $x$-and $y$-direction. The method applied to the ESCOMPTE data is described in more detail by Thürauf (2002). Interpolated ozone concentration fields and calculated horizontal ozone advection are given in Figs. 16-18.

As discussed in Section 3, the aircraft measurements between 5:44 and 6:44 UTC at $775 \mathrm{~m}$ MSL are performed in the transition zone between the top of NBL and the residual layer at a time when no chemical ozone production takes place. Due to different wind regimes, i.e., southwesterly winds in the southern part and easterly winds in the northern part of the measurement domain (Fig. 16), the ozone maximum in the northern part is transported to the west, while ozone rich air observed in the southern part is transported north- and northeastwards. The horizontal advection of ozone reaches values of about 20 ppbv $\mathrm{h}^{-1}$ at the eastern edge of the Rhône valley. 


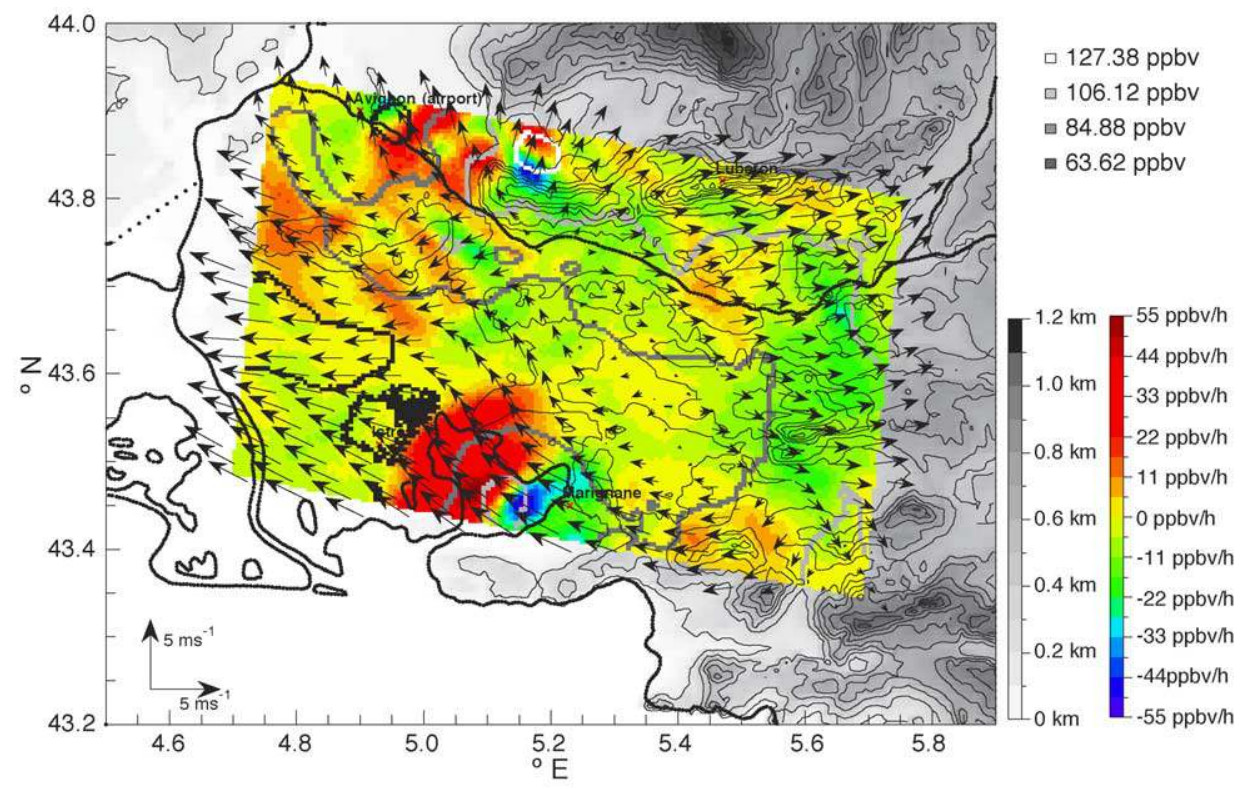

Fig. 18. Horizontal advection of ozone (coloured scale), horizontal wind vectors, and isolines of ozone concentrations (white, grey and black isolines, see upper scale) on June 25, 2001, from 14:09 and 15:34 UTC at $920 \mathrm{~m}$ MSL.

Between 11:00 and 12:05 UTC, a primary ozone maximum can be detected southwest of Luberon and a secondary one northeast of Marseille (Fig. 17a). The standard deviation of the calculated ozone concentration field (Fig. 17b), which is the square root of the Krige variance, yields information on the estimated error of this interpolated ozone distribution pattern (Thürauf, 2002). Values range from about 2 ppbv close to the flight legs to about 7 ppbv between two neighbouring flight legs. As a result of the ozone and wind field, the strongest horizontal advection of ozone appears south of Luberon (Fig. 17c). Hence, the strong increase of ozone at Luberon (Fig. 14) at noon can be attributed to horizontal advection of ozone within the mixed layer.

The pattern of horizontal advection of ozone between 14:09 and 15:34 UTC indicates an increase west of the Etang de Berre (Fig. 18). Furthermore, easterly winds in the Rhône valley above the sea breeze layer result in a transport of ozone-rich air towards the west. This kind of hand-over of polluted air from the PBL of mountainous areas to layers above the PBL in valleys has already been observed by Koßmann et al. (1999) and represents an effective process of transferring polluted air from the PBL to the free troposphere.

To determine the contribution of horizontal advection to the local change of ozone, lidar measurements at Vallon Dol/Marseille (L1) and Cadarache (L2) in the Durance valley were used to calculate the local change of ozone during the corresponding flight period and on the corresponding flight level (Table 2). The local change of ozone at Vallon Dol indicates a slight decrease of ozone during the whole day $\left(0\right.$ to $\left.-2 \mathrm{ppbv} \mathrm{h}^{-1}\right)$, while at 
Table 2

Calculated local change of ozone (from lidar data) and horizontal advection of ozone (from aircraft data) at the flight level for Vallon Dol (L1) and Cadarache (L2)

\begin{tabular}{lcll}
\hline & Time in UTC & $\begin{array}{l}\left(\left(\partial \overline{\mathrm{O}_{3}}\right) /(\partial t)\right), \\
\mathrm{ppbv} \mathrm{h}^{-1}\end{array}$ & $\begin{array}{l}\vec{v} \cdot \nabla \overline{\mathrm{O}_{3}}, \\
\mathrm{ppbv} \mathrm{h}^{-1}\end{array}$ \\
\hline Vallon Dol (L1) & $5: 44-6: 44$ & -1 & +3 \\
& $11: 00-12: 05$ & -2 & -20 \\
Cadarache (L2) & $14: 09-15: 34$ & \pm 0 & +5 \\
& $5: 44-6: 44$ & +3 & - \\
& $11: 00-12: 05$ & +2 & +10 \\
& $14: 09-15: 34$ & +5 & -5 \\
\hline
\end{tabular}

Cadarache, the ozone concentrations increase by a rate between 3 and $5 \mathrm{ppbv} \mathrm{h}^{-1}$. The horizontal advection of ozone, as derived from Figs. 16, 17c, and 18, reveals that only during the flight from 11:00 to 12:05 UTC, the increase at Cadarache and the decrease at Vallon Dol coincide with appropriate values of horizontal advection of ozone. So it must be concluded that during the morning and afternoon flights other processes and local effects are dominant, which cannot be estimated from measured data.

\section{Conclusions}

The aim of the present investigation was to analyse the mesoscale circulation systems in the ESCOMPTE domain together with the temporal evolution and spatial distribution of the ozone concentrations on IOP $2 b$.

IOP $2 \mathrm{~b}$ was characterised by a high pressure system with light to moderate synoptic winds, which are ideal prerequisites for the evolution of a summer smog situation and mesoscale circulation systems. Under nocturnal stable stratification, a heterogeneous wind field develops mainly under the effect of local orography. During daytime, when unstable stratification has established, different mesoscale circulation systems superimpose. In the Rhône valley, the sea breeze penetrates towards the north, resulting in a decrease of the mixed layer height from $1 \mathrm{~km}$ MSL at noon down to $400 \mathrm{~m}$ MSL in the afternoon. As the winds above the sea breeze layer come from the east, polluted air from the metropolitan area of Marseille leads to an increase of ozone at elevated layers above the $\mathrm{CBL}$ in the eastern part of the Rhone valley.

At the mountainous station of Luberon at $675 \mathrm{~m}$ MSL about $55 \mathrm{~km}$ north of Marseille, background ozone concentrations of 60 ppbv were observed during the night. Between 11 and 12 UTC, when the CBL top surpassed the height of the mountain summit, polluted air with ozone concentrations of about $120 \mathrm{ppbv}$ arrived from southerly directions, thus indicating the passage of the city plume of Marseille. At Cadarache and Vinon in the Durance valley, about $60 \mathrm{~km}$ inland, the ozone maximum at the surface and at flight level $920 \mathrm{~m}$ MSL appears between 14 and 15 UTC. At this time, southwesterly valley wind exists in the valley, while more southerly winds occur above. Hence, in the lower layers 
polluted air moves along the valley, while in the upper layers, the polluted air crosses the southern sidewalls of the Durance valley and propagates northwards. This finding highlights the height-dependent advection of ozone due to interacting mesoscale circulation systems. These dynamical processes need to be represented adequately in CTMs to result in a realistic forecast.

The ozone concentrations close to the coast increase weakly due to downward mixing during the morning hours but do not exceed the background concentration of $60 \mathrm{ppbv}$ measured in the residual layer during the night. This is consistent with the surface wind measurements, showing onshore winds and advection of less polluted air from the sea throughout the day.

Generally, the dense setup of ground-based stations, remote sensing instruments, and three aircraft flights on June 25, 2001, during IOP 2b of ESCOMPTE offer favourable conditions to analyse the mesoscale meteorological flow pattern in relation to the spatial distribution of pollutants and their transformation products. Nevertheless, this study also shows the limits of an analysis based purely on measurement data. Flow conditions over complex terrain in conjunction with spatially irregular emissions can hardly be sampled at sufficient spatial and temporal resolution. Model output compared with such data need to account for the limited representativeness of observations.

\section{References}

Becker, A., Scherer, B., Memmesheimer, M., Geiß, H., 2002. Studying the city plume of Berlin on 20 July 1998 with three different modelling approaches. J. Atmos. Chem. 42, 41-70.

Bischoff-Gauß, I., Kalthoff, N., Fiedler, F., 1998. The impact of secondary flow systems on air pollution in the area of Sao Paulo. J. Appl. Meteorol. 37, 269-287.

Bougeault, P., Binder, P., 2002. The Mesoscale Alpine programme. WMO Bull. 51, 14-17.

Carroll, J.J., Baskett, R.L., 1979. Dependence of air quality in a remote location on local and mesoscale transports: a case study. J. Appl. Meteorol. 18, 474-486.

Chalon, J.-P., André, M., Brenguier, J.-L., Druilhet, A., Gayet, J.-F., Flamant, P.H., Guillemet, B., Hauser, D., Kerr, Y., Pelon, J., Ravaut, M., Tanré, D., 1998. Les avions français de recherche atmosphérique et de télédétection. Météorologie 22, 14-44.

Corsmeier, U., Kalthoff, N., Kolle, O., Kotzian, M., Fiedler, F., 1997. Ozone concentration jump in the stable nocturnal boundary layer during a LLJ-event. Atmos. Environ. 31, 1977-1989.

Corsmeier, U., Hankers, R., Wieser, A., 2001. Airborne turbulence measurements in the lower troposphere onboard the research aircraft Dornier 128-6, D-IBUF. Meteorol. Z. 10, 315-329.

Corsmeier, U., Kalthoff, N., Vogel, B., Hammer, M.-U., Fiedler, F., Kottmeier, C., Volz-Thomas, A., Konrad, S., Glaser, K., Neininger, B., Lehning, M., Jaeschke, W., Memmesheimer, M., Rappenglück, B., Jakobi, G., 2002. Ozone and PAN formation inside and outside of the Berlin plume-process analysis and numerical process simulation. J. Atmos. Chem. 42, 289-321.

Cousin, F., Tulet, P., Rosset, R., 2004. Interaction between local and regional pollution during Escompte 2001: impact on surface ozone concentrations (IOP2a and 2b). Atmos. Res. 74, 117-137 (same issue).

Cros, B., Durand, P., Cachier, H., Drobinski, Ph., Frejafon, E., Kottmeier, C., Perros, P.E., Peuch, V.-H., Ponche, J.-L., Robin, D., Said, F., Toupance, G., Wortham, H., 2004. The ESCOMPTE program: an overview. Atmos. Res. 69, 241-279.

Donev, E., Zeller, K., Avramov, A., 2002. Preliminary background ozone concentrations in the mountain and coastal areas of Bulgaria. Environ. Pollut. 117, 281-286.

Fiedler, F., Borrell, P., 2000. TRACT. Transport of air pollutants over complex terrain. In: Laren, S., Fiedler, F., Borrell, P. (Eds.), Exchange and Transport of Air Pollutants Over Complex Terrain and the Sea. Springer Verlag, Berlin. 357 pp. 
Gallardo, L., Carrasco, J., Olivares, G., 2000. Analysis of ozone measurements at Cerro Tololo $\left(70^{\circ} \mathrm{W}, 30^{\circ} \mathrm{S}, 2200\right.$ m.a.s.l.) in Chile. Tellus, Ser. B Chem. Phys. Meteorol. 52, 50-59.

Güsten, H., Heinrich, G., Sprung, D., 1998. Nocturnal depletion of ozone in the upper Rhine valley. Atmos. Environ. 32, 1195-1202.

Hammer, M.-U., Vogel, B., Vogel, H., 2002. Findings on $\mathrm{H} 2 \mathrm{O} 2 / \mathrm{HNO} 3$ as an indicator for ozone sensitivity in Baden-Württemberg, Berlin-Brandenburg and the Po valley based on numerical simulations. J. Geophys. Res. 107,8190 .

Imhoff, R.E., Valente, R., Meagher, J.F., Luria, M., 1995. The production of $\mathrm{O}_{3}$ in an urban plume: airborne sampling of the Atlanta urban plume. Atmos. Environ. 29, 2349-2358.

Kalthoff, N., Horlacher, V., Corsmeier, U., Volz-Thomas, A., Kolahgar, B., Geiß, H., Möllmann-Coers, M., Knaps, A., 1999. The influence of valley winds on transport and dispersion of airborne pollutants in the Freiburg-Schauinsland area. J. Geophys. Res. 105 (D1), 1585-1597.

Klemm, O., Ziomas, I.C., Balis, D., Suppan, P., Slemr, J., Romero, R., Vyras, L.G., 1998. A summer air-pollution study in Athens, Greece. Atmos. Environ. 32, 2071-2087.

Koßmann, M., Vögtlin, R., Corsmeier, U., Vogel, B., Fiedler, F., Binder, H.-J., Kalthoff, N., Beyrich, F., 1998. Aspects of the convective boundary layer structure over complex terrain. Atmos. Environ. 32, 1323-1348.

Koßmann, M., Corsmeier, U., DeWekker, S.F.J., Fiedler, F., Vögtlin, R., Kalthoff, N., Güsten, H., Neininger, B., 1999. Observations of handover processes between the atmospheric boundary layer and the free troposphere over mountainous terrain. Contrib. Atmos. Phys. 72, 329-350.

Koßmann, M., Fiedler, F., 2000. Diurnal momentum budget analysis of thermally induced slope winds. Meteorol. Atmos. Phys. 75, 195-215.

Kurita, H., Ueda, H., Mitsumoto, S., 1990. Combination of local wind systems under gradient wind conditions and its contribution to the long-range transport of air pollutants. J. Appl. Meteorol. 29, 331-348.

Matheron, G., 1963. Principles of geostatistics. Econ. Geol. 58, 1246-1266.

Matheron, G., 1989. Estimating and Choosing. Springer Verlag, Berlin. 141 pp.

Melas, D., Ziomas, I., Klemm, O., Zerefos, C.S., 1998. Anatomy of the sea-breeze circulation in Athens area under weak large-scale ambient winds. Atmos. Environ. 32, 2223-2237.

Menut, L., Vautard, R., Flamant, C., Abonnel, C., Beekmann, M., Chazette, P., Flamant, P.H., Gombert, D., Guédalia, D., Kley, D., Lefebvre, M.P., Lossec, B., Martin, D., Mégie, G., Perros, P., Sicard, M., Toupance, G., 2000. Measurements and modeling of atmospheric pollution over the Paris area: an overview of the ESQUIF project. Ann. Geophys. 18, 1467-1481.

Neftel, A., 1999. Examples of the importance of trace gas measurements in the Milan ozone plume. Analusis 27, $325-327$.

Oke, T.R., 1987. Boundary Layer Climates. Methuen, London. 435 pp.

Saïd, F., Corsmeier, U., Kalthoff, N., Kottmeier, C., Lothon, M., Wieser, A., Hofherr, T., Perros, P., 2004. ESCOMPTE experiment: intercomparison of four aircraft dynamical, thermodynamical, radiative and chemical measurements. Atmos. Res. 74, 217-252 (same issue).

Schaller, E., Schlünzen, K.H., Ebel, A., 2001. Evaluierungsstrategien für Chemie-Transportmodelle. Promet 27, $17-30$.

Thürauf, J., 2002. Windsysteme und Spurenstoffausbreitung während ESCOMPTE. Diploma thesis. Institut für Meteorologie und Klimaforschung, Universität Karlsruhe/Forschungszentrum Karlsruhe, Karlsruhe.

Vautard, R., Menut, L., Beekmann, M., Chazette, P., Flamant, P.H., Gombert, D., Guédalia, D., Kley, D., Lefebvre, M.-P., Martin, D., Mégie, G., Perros, P., Toupance, G., 2003. A synthesis of the air pollution over the Paris region (ESQUIF) field campaign. J. Geophys. Res. 108 (D17), 8558.

Vogel, B., Vogel, H., Fiedler, F., 1992. Numerical simulation of the interaction of transport, diffusion, and chemical reactions in an urban plume. NASA Conf. Publ. 3266, 97-100.

Vogel, B., Fiedler, F., Vogel, H., 1995. Influence of topography and biogenic volatile organic compounds emission in the state of Baden-Württemberg on ozone concentrations during episodes of high air temperatures. J. Geophys. Res. 100, 22907-22928.

Vogel, H., Memmesheimer, M., Reimer, E., Winkler, P., Fiedler, F., 2000. Typischer zeitlicher Verlauf von Photsmog-Episoden. Promet 26, 112-119.

Volz-Thomas, A., Geiß, H., Kalthoff, N., 2000. Schauinsland ozone precursor experiment (SLOPE96): scientific background and main results. J. Geophys. Res. 105 (D1), 1553-1561. 
Wakimoto, R.M., McElroy, J.L., 1986. Lidar observation of elevated pollution layers over Los Angeles. J. Clim. Appl. Meteorol. 25, 1583-1599.

Wotawa, G., Kromp-Kolb, H., 2000. The research project VOTALP—general objectives and main results. Atmos. Environ. 34, 1319-1322.

Whiteman, C.D., 2000. Mountain Meteorology. Oxford University Press, New York. 355 pp.

Ziomas, I.C., 1998. The Mediterranean campaign of photochemical tracers-transport and chemical evolution (MEDCAPHOT-TRACE): an outline. Atmos. Environ. 32, 2045-2053. 